\title{
A monograph of the Hydriastele wendlandiana group (Arecaceae: Hydriastele)
}

\author{
Peter Petoe $^{1}$ (D), Rodrigo Cámara-Leret ${ }^{1} \&$ William J. Baker ${ }^{1}$
}

Summary. A taxonomic revision is presented of the Hydriastele wendlandiana group, a well-defined species grouping within the Indo-Pacific palm genus Hydriastele that occurs in New Guinea, the Bismarck Archipelago and northern Australia. We accept five species: Hydriastele kasesa, H. rheophytica, H. variabilis, H. wendlandiana and $H$. apetiolata sp. nov. and provide fundamental information about each of those taxa including a summary of the group's taxonomic history and phylogeny, a distribution map, a key to the species, species descriptions with scientific illustrations, and IUCN Red List assessments.

Key Words. Areceae, Arecoideae, Hydriastele microspadix, Indonesia, Papua New Guinea, Palmae, taxonomy.

\section{Introduction}

The palm genus Hydriastele $\mathrm{H}$. Wendl. \& Drude (Arecoideae: Areceae) currently contains 49 accepted species (Govaerts et al. 2017). Most of these occur in Papuasia, but the genus extends to Sulawesi, northern Australia, Fiji and Palau (Dransfield et al. 2008). The species are an important and conspicuous component of the palm floras in the areas in which they occur. Some of the species are used in horticulture (Riffle et al. 2012) whilst others are of great significance for subsistence and livelihoods (Essig 1982).

Members of Hydriastele display different growth habits ranging from small and clustered understorey palms to very robust, solitary canopy emergents. All species have reduplicately pinnate leaves, a welldefined crownshaft and leaflets that are irregularly jagged at the tip (praemorse). The floral arrangement, with flowers arranged in units of three (triads), is typical of the Arecoideae, and in Hydriastele the triads are moreover inserted throughout the length of the rachillae. These ultimate inflorescence axes are inserted closely together and are swept forward giving the inflorescence a horsetail-like appearance. The staminate flowers are larger than the pistillate flowers and have lanceolate, valvate petals that vary slightly in size (Dransfield et al. 2008).

The monophyly of Hydriastele is well supported, as is its placement in the major Indo-Pacific tribe Areceae, but current molecular evidence is insufficient to place the genus to subtribe (Loo et al. 2006; Dransfield et al. 2008; Baker et al. 2009; Baker et al. 2011; Baker \& Dransfield 2016). The phylogenetic relationships among the species of Hydriastele have been explored (Loo et al. 2006). Here, we present a monograph of an infrageneric species grouping within Hydriastele, a monophyletic group identified by Loo et al. (2006) that we term Hydriastele wendlandiana group. It occurs in New Guinea, the Bismarck Archipelago, northern Australia, and immediately adjacent islands, and is distinguished from the rest of the genus by its slender to moderate growth habit combined with protogynous inflorescences in which the stigmas are congenitally exposed (i.e. not covered by perianth, even in bud; Essig 1973; Uhl \& Dransfield 1987). We focus on this group because it is common throughout much of New Guinea, widely used by local people and is ecologically important. Moreover, the taxonomy of the group is very poorly understood and has not been the focus of a modern monographic revision. Prior to this treatment 10 species were accepted: Hydriastele wendlandiana (F. Muell.) H. Wendl. \& Drude, H. geelvinkiana (Becc.) Burret, H. variabilis (Becc.) Burret, H. microspadix (Warb. ex K. Schum. \& Lauterb.) Burret, H. kasesa (Lauterb.) Burret, $H$. beccariana Burret, $H$. rostrata Burret, $H$. carrii Burret, H. lepidota Burret and H. rheophytica Dowe \& M. D. Ferrero (Baker \& Loo 2004).

\section{Material and methods}

We examined 128 herbarium specimens from key international herbaria (A, BRI, CANB, FI, K, LAE, MEL; herbarium abbreviations following Thiers [2017]) including dried and spirit material, photographs, and field notes. A morphological species concept (Davis \& Heywood 1963; McDade 1995) was used in which co-varying characters and disjunct character states were taken as evidence of support for the existence of different species.

Accepted for publication 31 January 2018. Published online 26 March 2018

1 Herbarium, Royal Botanic Gardens, Kew, Richmond, Surrey, TW9 3AE, UK. e-mail: p.petoe@kew.org 
Spirit material was used as far as possible for floral and fruit descriptions. Before dissecting, dried material was rehydrated by boiling, but because this does not eliminate drying artefacts, e.g. the pericarp still appeared shrunken, we have indicated the use of dried material in appropriate places in the descriptions.

Coordinates used for the distribution map were harvested directly from specimens or derived from online and hard-copy gazetteers. We created the map using Quantum GIS computer software (Quantum GIS Development Team 2017), and in doing so we supplemented the new coordinates we had obtained for Australia, derived from the specimens we have cited in this monograph, with what was already known about the distribution of Hydriastele wendlandiana in Australia (Dowe 2010). GeoCAT (Bachman et al. 2011) was used to make preliminary IUCN conservation assessments following the International Union for the Conservation of Nature (IUCN) categories and criteria version 3.1 (IUCN 2001). Palm terminology used in the descriptions is based on the Genera Palmarum glossary (Dransfield et al. 2008) supplemented by The Kew Plant Glossary (Beentje 2016).

\section{Taxonomic history and phylogeny}

Mueller described the first species in the group in 1870 as Kentia wendlandiana F. Muell. from northern Australia. The same species was soon renamed Hydriastele wendlandiana when, in 1875, Wendland \& Drude erected the genus Hydriastele. In 1877, Nenga geelvinkiana Becc. and $N$. variabilis Becc. were described by Beccari from northwest New Guinea and subsequently Schumann \& Lauterbach described Kentia microspadix Warb. ex K. Schum \& Lauterb. and Ptychosperma kasesa Lauterb. from Kaiser-Wilhelmsland
(German New Guinea) and the Bismarck Archipelago in 1900 and 1911 respectively. All four species were subsequently transferred to Adelonenga (Becc.) Hook. f. by Beccari (1885 and 1914) and then eventually to Hydriastele by Burret (1937) who recognised that Adelonenga was congeneric with Hydriastele. Burret also described four species himself; Hydriastele beccariana (1928), H. carrii (1936), H. rostrata (1937) and H. lepidota (1939).

Burret's generic delimitation of Hydriastele was accepted in the first modern genus-level monograph of palms (Uhl \& Dransfield 1987), and this circumscription corresponds with the Hydriastele wendlandiana group, which we treat in this monograph. A further species from the highlands of Papua, Hydriastele rheophytica, was added to this group by Dowe \& Ferrero (2000). Subsequently, the molecular phylogenetic analysis of Loo et al. (2006) led to a substantial expansion of the generic limits of Hydriastele. Their study revealed that Hydriastele sensu Burret (1937) is monophyletic, but embedded within a larger paraphyletic group of three closely related genera, Gronophyllum Scheff., Gulubia Becc. (both polyphyletic) and Siphokentia Burret (paraphyletic). As a result, Hydriastele was expanded to include these three genera (Baker \& Loo 2004) and this delimitation prevails today (Dransfield et al. 2008; Baker \& Dransfield 2016).

\section{Revised taxonomy and distribution}

Following our revision, we accept five species in the Hydriastele wendlandiana group, in contrast with the ten species recognised prior to this publication. The accepted species are: $H$. apetiolata sp. nov., H. kasesa, $H$. rheophytica, $H$. variabilis and $H$. wendlandiana. The known distribution of these species is presented in Map 1.

\section{Key to the species of the Hydriastele wendlandiana group}

1. Clustering palm; stem pliable and usually leaning; leaflets linear, thin and soft, terminal leaflets comprising c. 2 - 3 folds, basal leaflets obliquely praemorse apically; restricted to stream banks . . . . . . . . . 3. H. rheophytica Clustering or solitary palm; stem rigid and usually erect; leaflets linear or cuneate, relatively stiff and papery, terminal leaflets comprising 3 - 16 folds (very rarely fewer folds), basal leaflets pointed, obliquely praemorse or truncately praemorse apically; may occur on stream banks, but not restricted to this habitat $\ldots \ldots \ldots \ldots \ldots \ldots \ldots$

2. Clustering palm; leaflets regularly to subregularly arranged, basal leaflets pointed to obliquely praemorse apically or if truncately praemorse apically then in addition with apetiolate adult leaves $\ldots \ldots \ldots \ldots \ldots \ldots \ldots \ldots$

Clustering or solitary palm; leaflets usually irregularly arranged, with a group of closely spaced single- or bi-fold leaflets in the middle of the leaf rachis, or leaflets regularly arranged with the basal leaflets being truncately praemorse apically and inserted onto a rachis that extends into a well-defined petiole $\ldots \ldots \ldots \ldots \ldots \ldots \ldots$

3. 4- 7 leaves in crown; stem up to $4 \mathrm{~cm}$ in diam.; sheath $27-45 \mathrm{~cm} \mathrm{long,} \mathrm{crownshaft} 33-70 \mathrm{~cm}$; petiole more than $9 \mathrm{~cm}$ long; leaflets 11 - 23 each side of rachis with the basal leaflets being pointed or obliquely praemorse apically; juvenile leaves pinnately compound; inflorescence $12-25 \mathrm{~cm}$ long with 1 or 2 orders of branching; primary branches bearing up to one rachilla each; fruit ellipsoid to ovoid; endosperm deeply ruminate $\ldots \ldots \ldots \ldots \ldots \ldots \ldots \ldots \ldots \ldots \ldots \ldots \ldots \ldots \ldots$ variabilis

7 - 10 leaves in crown, stem more than $4.5 \mathrm{~cm}$ in diam.; sheath c. $60 \mathrm{~cm}$ long, crownshaft $120-150 \mathrm{~cm}$; petiole absent; leaflets 23 - 25 each side of rachis with the basal leaflets being obliquely or truncately praemorse; 
juvenile leaves entire bifid; inflorescence 25 - $35 \mathrm{~cm}$ long with 2 orders of branching; primary branches bearing up to 3 rachillae each; fruit subglobose; endosperm ruminate . . . . . . . . . . 1. H. apetiolata

4. Slender palm, stem up to $3.8 \mathrm{~cm}$ in diam.; sheath $15-30 \mathrm{~cm}$ long, crownshaft $30-35 \mathrm{~cm}$; leaflets $6-13$ each side of rachis; inflorescence branched to 1 or 2 orders, with $5-10$ primary branches bearing up to 3 rachillae

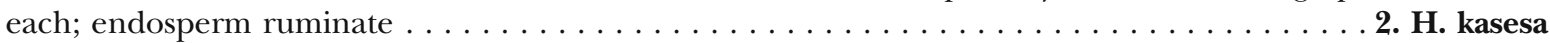
Slender to moderate palm, stem up to $10 \mathrm{~cm}$ in diam.; sheath $40-73 \mathrm{~cm}$ long, crownshaft $30-160 \mathrm{~cm}$; leaflets 12 - 30 on each side of rachis (rarely 12 - 13 per side); inflorescence usually branched to 2 orders, with $8-15$ primary branches bearing up to 5 rachillae each; endosperm homogeneous or

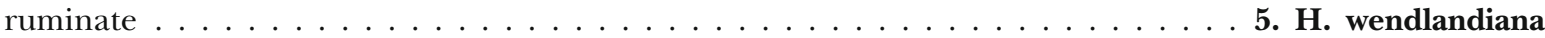

\section{Taxonomic treatment}

1. Hydriastele apetiolata Petoe $\mathcal{E}$ W. J. Baker sp. nov. Type: Indonesia, Papua Province, Mimika Regency, Timika, Nursery: Kuala Kencana, [4 4 47'S, $136^{\circ} 33$ 'E], c. 50 m elev., 27 Feb. 1998, Baker et al. 884 (holotype K!; isotypes $\mathrm{BH}, \mathrm{BO}, \mathrm{L}, \mathrm{MAN})$.

http://www.ipni.org/urn:lsid:ipni.org:names:60475907-2

Clustering, moderately slender palm to c. $6 \mathrm{~m}$ tall, bearing $7-10$ leaves per crown. Stem $4.5-6 \mathrm{~cm}$ in diam., smooth and dark with lighter blotches; internodes $9-25 \mathrm{~cm}$ long. Leaves to $125 \mathrm{~cm}$ long; sheath c. $60 \mathrm{~cm}$ long, with lacerate-peltate, dark purple scales and ferrugineous filaments sometimes covered with scurfy scales, crownshaft $120-150 \mathrm{~cm}$ long; petiole lacking; rachis slightly arching, indumentum as sheath, if less dense; leaflets 23 - 26 each side of rachis, arranged regularly, borne c. $3.5-4.5 \mathrm{~cm}$ apart, \pm horizontal, praemorse apically, transverse veinlets obscure, ramenta present; terminal leaflets c. $25-35 \times$ $4 \mathrm{~cm}$, comprising $4-6$ folds, cuneate; longest leaflet in middle of rachis c. $70-90 \times 2-3 \mathrm{~cm}$, single-fold,

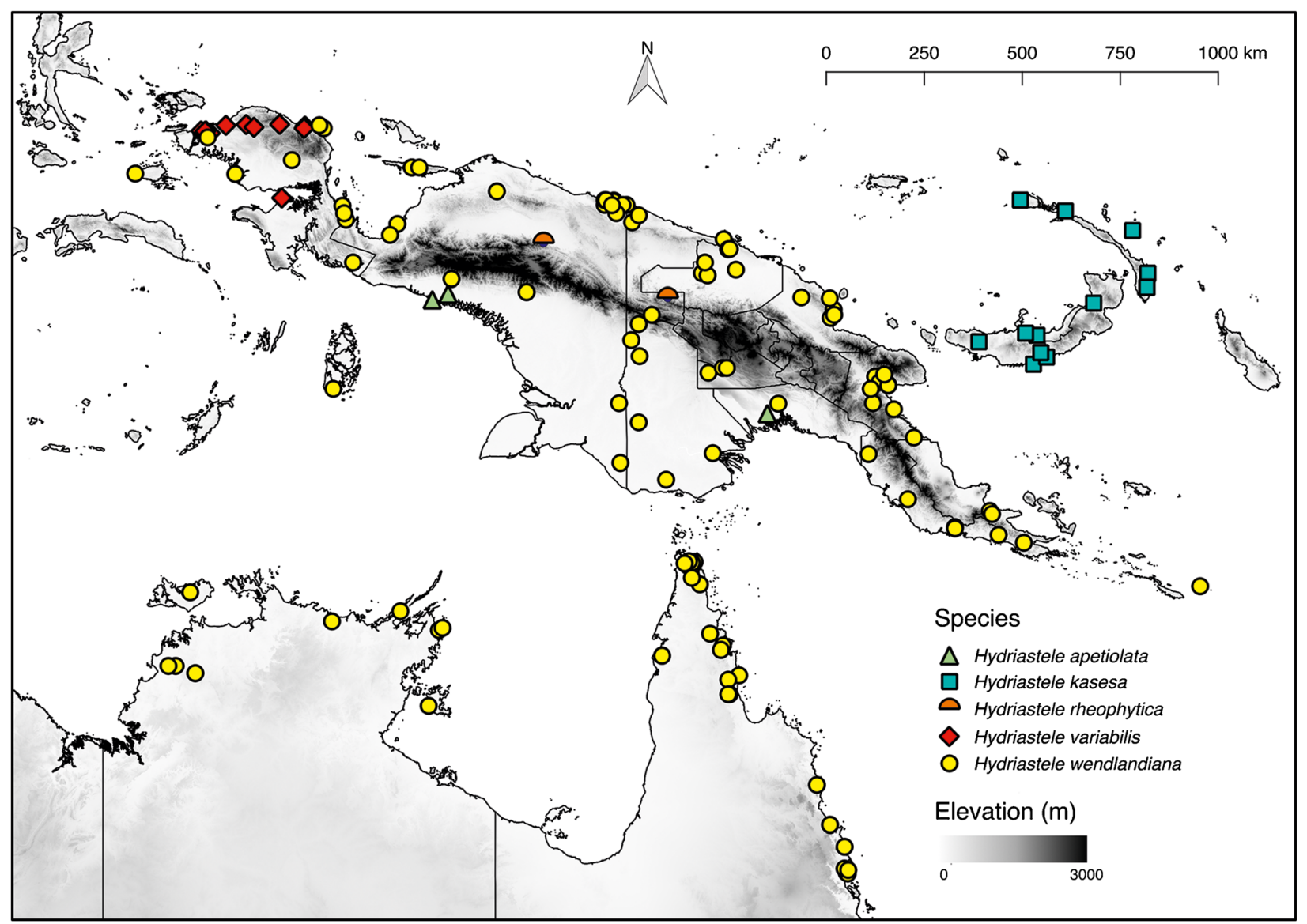

Map 1. Distribution map of the species of the Hydriastele wendlandiana group. Species and elevation legends are included within the figure. 
linear; basal leaflets single-fold, \pm grouped, linear, obliquely or truncately praemorse apically; juvenile leaves different from adult leaves, entire and bifid, with or without petiole, with lamina $100-130 \mathrm{~cm}$ long. Inflorescences 25 - $35 \mathrm{~cm}$ long including $3.5-$ $5.5 \mathrm{~cm}$ peduncle, branched to 2 orders; prophyll not seen, caducous; peduncular bract attached $1-1.5 \mathrm{~cm}$ above the prophyll; primary branches 8 , to $27.5 \mathrm{~cm}$ long, closely spaced and bearing up to 3 rachillae each; rachillae up to $27.5 \mathrm{~cm}$ long, $2-3 \mathrm{~mm}$ in diam.; triads $5-8 \mathrm{~mm}$ apart, opposite and decussate. Staminate flower $11-12 \times 5-6 \mathrm{~mm}$ shortly before anthesis; calyx c. $1 \times 3 \mathrm{~mm}$, sessile, consisting of 3 slightly different triangular and basally connate sepals, petals unequal in size $11-12 \times 3-6 \mathrm{~mm}$, valvate; stamens $6-8$; filaments c. $0.5 \times 0.3-0.4 \mathrm{~mm}$, variously epipetalous, conical; anthers $4-5 \times 0.4-0.7 \mathrm{~mm}$, pointed; pistillodes 3-5 minute lobes. Pistillate flowers $2-3 \times 2.5-3 \mathrm{~mm}$ near anthesis, \pm conical; sepals $1.5-2 \times 1.2-2 \mathrm{~mm}$, rounded, imbricate, interior surface striate; petals $1.8-2.5 \times 2-4$ $\mathrm{mm}$, rounded with slightly acuminate tips, broadly imbricate; ovary $1.5-2 \times 0.8-1.3 \mathrm{~mm}$, ovoid; well-defined style lacking; stigma minute and congenitally exposed; staminodes $3-6$, tooth-like, connected by a thin basal ring. Fruits $7.4-9.4 \times 6.6-8.2 \mathrm{~mm}$ when ripe, subglobose, smooth, drying ridged; perianth appressed to the fruit; pericarp c. $0.8 \mathrm{~mm}$ thick, epicarp red. Seeds $5.1-7.2 \times 5-$ $6.8 \mathrm{~mm}$, globose to subglobose; hilum lateral, elongate; endosperm ruminate (Fig. 1).

RECOGNITION. Distinguished from all other species in the group by its apetiolate adult leaves and entire bifid juvenile leaves.

DISTRIBUTION. Known from two localities on the southern coast of New Guinea (Map 1).

SPECIMENS EXAMINED. INDONESIA. PAPUA PROVINCE: Mimika Regency, Timika, Nursery, Kuala Kencana [447'S 136 33'E], c. 50 m elev., 27 Feb. 1998, Baker et al. 884 (BH, BO, K!, L, MAN); Mimika Regency, Timika, East Levee by drowned forest, $5 \mathrm{~km}$ S of Kpg Kali Kopi, Loc 11, [4³9'S 136 55'E], 20 m elev., 18 Feb. 1998, Witono 20 (BH, BO, K, L!, MAN); Mimika Regency, Timika, East Levee by drowned forest, $5 \mathrm{~km} \mathrm{~S}$ of Kpg Kali Kopi, Loc 11, [4³9'S 136 55'E], 20 m elev., 18 Feb. 1998, Witono 21 (BO, K!, MAN). PAPUA NEW GUINEA. GULF PROVINCE: Kikori Distr., Kopi-Kikori road, $3 \mathrm{~km}$ NW of Kikori, [7²4'S $144^{\circ} 13^{\prime} \mathrm{E}$ ], 40 m elev., 21 Nov. 2000, Baker et al. 1103 (AAU, BRI, K!, L, LAE, NY).

HABITAT. This species is known from cleared lowland rainforest in Timika, Indonesia, and from hill forest with abundant Hydriastele, Licuala and Orania in Kikori, Papua New Guinea; 20 - 50 m elevation.

LOCAL NAMES AND USES. None recorded. GLOBAL CONSERVATION STATUS. Data Deficient (DD). More data are needed about the distribution and abundance of this species.
NOTES. Hydriastele apetiolata is known from three collections, all of which were sequenced for two genes by Loo et al. (2006) along with other specimens belonging to the Hydriastele wendlandiana group. In the resulting phylogenetic trees, $H$. apetiolata is distinguished by consistently falling outside of a wellsupported clade containing all other members of the group that were included in the study. This noticeable phylogenetic pattern is consistent with the morphological distinctness of the species. The species is highly distinctive on account of its apetiolate leaves and the bifid juvenile leaves.

The type was collected from a palm that had been dug up from the wild, not far from the nursery in Timika, to where it was subsequently transplanted.

2. Hydriastele kasesa (Lauterb.) Burret (1937: 484). Ptychosperma kasesa Lauterb. (Lauterbach 1911: 357). Adelonenga kasesa (Lauterb.) Becc. (Beccari 1914: 26). Type: Papua New Guinea, New Ireland Province, Namatanai, Peekel 109 (holotype B十, isotype FI!).

Solitary or clustering, slender palm with $5-15$ stems per clump, 2-6 m tall, bearing $6-8$ leaves per crown. Stem $1.5-3.8 \mathrm{~cm}$ in diam., smooth and dark with blotches; internodes c. 2 - $10 \mathrm{~cm}$ long. Leaves $70-$ $150 \mathrm{~cm}$ long including petiole; sheath $15-30 \mathrm{~cm}$ long, covered with lacerate-peltate, dark purple scales sometimes attached to ferrugineous filaments and covered by \pm aggregated scurfy scales, crownshaft 30 $35 \mathrm{~cm}$ long; petiole $15-40 \mathrm{~cm}$, indumentum as sheath; rachis c. $35-90 \mathrm{~cm}$, indumentum as sheath; leaflets $6-$ 13 each side of rachis, mostly single-fold, arranged irregularly and usually with a clear interruption right above a group of closely spaced single- or bi-fold leaflets in different planes in the middle of rachis, cuneate and praemorse apically, ramenta lacking (always absent?), adaxially dark green - bluish green and somewhat glossy, abaxially a little paler, transverse veinlets obscure, thick and papery; terminal leaflets $16-27 \times 5-10 \mathrm{~cm}$, comprising $5-8$ folds; middle leaflet to $45 \times 10 \mathrm{~cm}$; basal leaflets truncately praemorse apically. Inflorescences $17-$ $30 \mathrm{~cm}$ long including $2-4 \mathrm{~cm}$ peduncle, branched to 1 or 2 orders; prophyll $15-27 \times 3-4 \mathrm{~cm}$; peduncular bract attached $0.5-1 \mathrm{~cm}$ above the prophyll; primary branches 5 - 10, to $23.5 \mathrm{~cm}$ long, closely spaced and bearing up to 3 rachillae each; rachillae up to $23.5 \mathrm{~cm}$ long, $1-2(-3) \mathrm{mm}$ in diam.; triads $4-7 \mathrm{~mm}$ apart, opposite and decussate. Staminate flowers $8 \times 3-4 \mathrm{~mm}$ when dry, shortly before anthesis; calyx c. $1 \times 2 \mathrm{~mm}$, sessile, consisting of 3 slightly different triangular and basally connate sepals, petals unequal in size $7 \times 2-4$ $\mathrm{mm}$, valvate, white - pink; stamens 6 ; filaments c. $0.5 \times$ $0.2 \mathrm{~mm}$, variously epipetalous, conical; anthers $3-3.5 \times$ $0.5-1 \mathrm{~mm}$, pointed; pistillodes forming minute clump. 


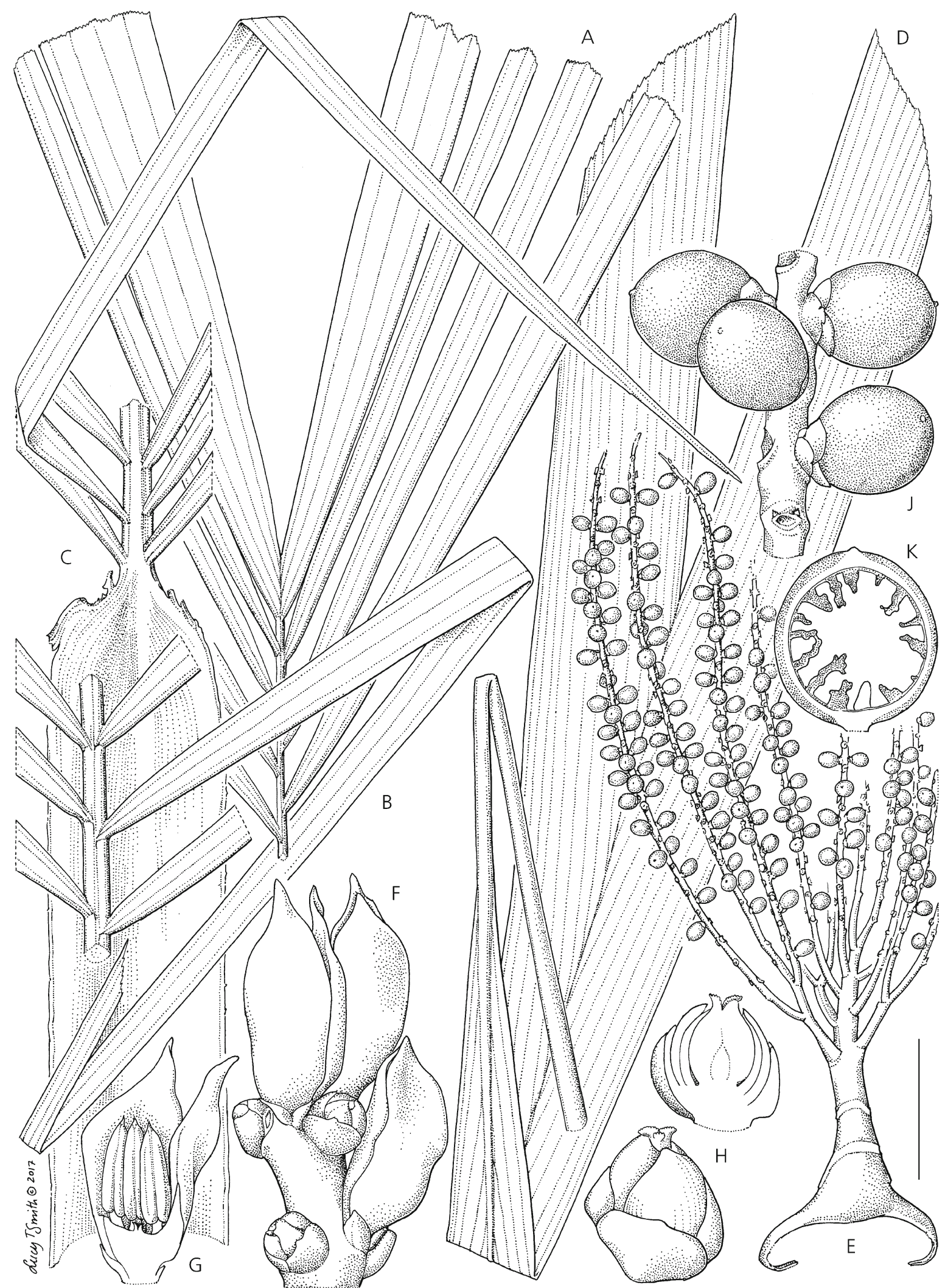

Fig. 1. Hydriastele apetiolata. A leaf apex; B mid-leaf portion; C leaf base with sheath; D juvenile leaf; $\mathrm{E}$ infructescence; $\mathrm{F}$ portion of rachilla with triads; $\mathrm{G}$ staminate flower in longitudinal section; $\mathrm{H}$ pistillate flower whole and in longitudinal section; J portion of rachilla with fruits; K fruit in longitudinal section. Scale bar: A - C, E $6 \mathrm{~cm}$; D $12 \mathrm{~cm} ; \mathrm{F} 7 \mathrm{~mm} ; \mathrm{G} 5 \mathrm{~mm} ; \mathrm{H} 3.3 \mathrm{~mm} ; \mathrm{J} 1.5 \mathrm{~cm} ; \mathrm{K} 1 \mathrm{~cm}$. All from Baker 884. DRAWN BY LUCY T. SMITH. 
Pistillate flowers c. $2.5 \times 2.5 \mathrm{~mm}$ when dry, shortly after anthesis, \pm conical; sepals $1.8-2 \times 2-3 \mathrm{~mm}$, rounded, imbricate, interior surface striate; petals c. $2.2 \times 3 \mathrm{~mm}$, rounded with short obtuse tips, broadly imbricate; ovary c. $2 \times 1-1.5 \mathrm{~mm}$, ovoid; well-defined style lacking; stigma minute and congenitally exposed; staminodes c. 2, toothlike and minute. Fruits c. $12 \times 9 \mathrm{~mm}$ when ripe, ovoid to subglobose, smooth and drying wrinkled or ridged; perianth appressed to the fruit; epicarp red or scarlet, shiny. Seeds c. $6.7 \times 5.4 \mathrm{~mm}$ when dry, ovoid; hilum lateral, elongate; endosperm ruminate (Fig. 2).

DISTRIBUTION. This species occurs in West New Britain Province, East New Britain Province, and New Ireland Province in the Bismarck Archipelago (Map 1).

SPECIMENS EXAMINED. PAPUA NEW GUINEA. WEST NEW BRITAIN PROVINCE: Eiliak, [545'S 149 5'E], 15 m elev., 7 May 1958, White 10070 (BRI, CANB!, L!, LAE); Gasmata Sub-distr., Gasmata patrol post, [6 ${ }^{\circ} 15^{\prime} \mathrm{S}$ $150^{\circ} 19^{\prime} \mathrm{E}$ ], $40 \mathrm{~m}$ elev., 30 May 1987, Kerenga 62320 (LAE!); Gasmata Sub-distr., 6 miles E of Fullerborn Harbour [6 $6^{\circ} \mathrm{S} 150^{\circ} 38^{\prime} \mathrm{E}$ ], $300 \mathrm{~m}$ elev., 8 May 1973, Isles 34405 (A, BRI, K!, L!, LAE, CANB!); Talasea Subdistr., Koimumu-Lavege Road, [5 $36^{\prime} \mathrm{S} 150^{\circ} 25^{\prime} \mathrm{E}$ ], 17 April 1959, White 10889 (A, BRI, K!, LAE); Talasea Subdistr., Kimbe, [5 33 'S $150^{\circ} 9^{\prime} \mathrm{E}$ ], $0 \mathrm{~m}$ elev., 26 April 1972, Essig 55214 (LAE!); Mt Klangal, 25 miles NNE of Gasmata, [6 ${ }^{\circ} 00^{\prime} \mathrm{S} 150^{\circ} 30^{\prime} \mathrm{E}$ ], 800 m elev., 15 May 1973, Croft 15567 (BH, L!, LAE). EAST NEW BRITAIN: Rabaul Sub-distr., Matanakunei, [4 ${ }^{\circ} 52^{\prime} \mathrm{S} 151^{\circ} 43$ 'E], 0 m elev., 29 March 1968, Ridsdale 38004 (BH, BRI, CANB, L!). NEW IRELAND PROVINCE: Namatanai, Peekel 109 (B十, FI!); Namatanai Sub-distr., Hans Meyer Range, Danfu R. Valley about $8 \mathrm{~km} \mathrm{~W}$ and upstream of the Danfu bridge nr Manga, [4 $4^{\circ} 11^{\prime} \mathrm{S} 152^{\circ} 57^{\prime} \mathrm{E}$ ], $800 \mathrm{~m}$ elev., 14 Feb. 1970, Sands 866 (K!, L, LAE); inland from Lossuk to Bagaterra, [245'S $151^{\circ} 4^{\prime} \mathrm{E}$ ], 0 m elev., 3 Feb. 1967, Coode 29729 (LAE!); near the junction of the Niagara and Weitin R., [4 $30^{\prime} \mathrm{S} 152^{\circ} 56^{\prime} \mathrm{E}$ ], $240 \mathrm{~m}$ elev., 19 Jan. 1994, Takeuchi 9902 (A!); near the junction of the Niagara and Weitin R., [4³0'S 152 $56^{\circ}$ 'E], $240 \mathrm{~m}$ elev., Jan. 1994, Takeuchi 9994 (A!); Sub-distr. Lamet, West New Hanover, $2 \mathrm{~km} \mathrm{E}$ of Metemulai village, [2 30 'S $150^{\circ} 2^{\prime} \mathrm{E}$ ], $50 \mathrm{~m}$ elev., 7 Oct. 1974, Croft 65490 (BH, L!, LAE); Namatanai Sub-province, Lihir Island, Mt Tementa above Palie Mission, [ $3^{\circ} 12^{\prime} \mathrm{S} 152^{\circ} 36^{\prime} \mathrm{E}$ ], 600 m elev., 7 Nov. 1984, Gideon 57205 (L!, LAE, USP).

HABITAT. Hydriastele kasesa occurs in the understorey of lowland tropical primary rainforest, occasionally in swampy areas or on stream banks, and on premontane mixed forest slopes and ridges, on clay-loam; $0-800$ m elevation.

LOCAL NAMES AND USES. None recorded. GLOBAL CONSERVATION STATUS. Least Concern (LC). Hydriastele kasesa is relatively widely distributed with an EOO of c. $113,000 \mathrm{~km}^{2}$. The species' small AOO of 48 $\mathrm{km}^{2}$ is most likely a low estimate due to under-collecting. It has been reported as common in some localities. The biggest future threat appears to be deforestation and land-use change (Shearman et al. 2008; Global Forest Watch 2017).

NOTES. This species is distinguished by its slender habit with sheaths of $15-30 \mathrm{~cm}$ in length, leaves with $6-13$ pairs of irregularly arranged leaflets, the basal ones of which are truncately praemorse apically, and rather small inflorescences with 5-10 primary branches. Hydriastele kasesa can be confused with $H$. wendlandiana, which is the only other species in the group with a similar leaflet arrangement, but $H$. wendlandiana is normally not quite as slender, has longer sheaths (40 $73 \mathrm{~cm})$, nearly always more numerous leaflets $(12-30$ per side), and the inflorescences have $8-15$ primary branches. The distribution of $H$. kasesa does not appear to overlap with that of any other member of the $H$. wendlandiana group.

3. Hydriastele rheophytica Dowe $\mathcal{E}^{2}$ M. D. Ferrero (2000: 195). Type: Indonesia, Papua Province, Idenburg R., Araucaria Creek [3 ${ }^{\circ} 29^{\prime} \mathrm{S} 139^{\circ} 6^{\prime} \mathrm{E}$ ], March 1939, Brass 13700 (holotype A!, isotype L!).

Clustering, slender palm with up to 30 stems per clump, $4-6 \mathrm{~m}$ tall, bearing $4-12$ leaves per crown. Stem $2-$ $2.5 \mathrm{~cm}$ in diam., pliable, cream with red patches turning green; internodes to $14 \mathrm{~cm}$ long. Leaves c. $95-120 \mathrm{~cm}$ long including petiole; sheath 40 - $45 \mathrm{~cm}$ long, dark green, coated with lacerate-peltate, dark purple scales sometimes covered by scurfy scales, petiole $20-30 \mathrm{~cm}$ long, pliable, indumentum as sheath; rachis c. $60-80 \mathrm{~cm}$ long, slightly arching, indumentum as sheath; leaflets 18 32 each side of rachis, arranged \pm regularly at $2-5 \mathrm{~cm}$ intervals, linear and praemorse, adaxially dark green, abaxially slightly paler green, transverse veinlets obscure, ramenta present, thin and soft; terminal leaflets $22-27 \times$ $0.7-2 \mathrm{~cm}$, comprising $2-3$ folds; sub-apical leaflets c. $30 \times$ $0.7-2 \mathrm{~cm}$, single-fold; basal leaflets c. $40 \times 1.2-2 \mathrm{~cm}$, single-fold, obliquely praemorse apically. Inflorescences $16-$ $30 \mathrm{~cm}$ long including $2.5-7 \mathrm{~cm}$ peduncle, branched to 1 or 2 orders; prophyll to c. $20 \mathrm{~cm}$ long; first peduncular bract attached c. $0.8 \mathrm{~cm}$ above the prophyll; primary branches up to 10 , to $20 \mathrm{~cm}$ long, closely spaced and bearing up to 2 rachillae each; rachillae 5 - 15 per inflorescence, $1-3 \mathrm{~mm}$ in diam.; triads c. $3-5 \mathrm{~mm}$ apart, opposite and decussate. Staminate flowers $6-8 \times 3-4 \mathrm{~mm}$ when dry, pinkish cream; calyx $1-1.5 \times 1.5-2 \mathrm{~mm}$, sessile, with 3 slightly different triangular and basally connate sepals; petals unequal in size, $5.2-8 \times 3-5 \mathrm{~mm}$, valvate; stamens 6 ; filaments $0.5-1 \times 0.5-0.8 \mathrm{~mm}$, variously epipetalous, tubular - conical; anthers $3-4 \times 1 \mathrm{~mm}$, pointed; pistillodes absent. Pistillate flowers $2-2.5 \times 2 \mathrm{~mm}$ when dry, close to anthesis, \pm conical; sepals $1.5-2 \times 2.5-$ 


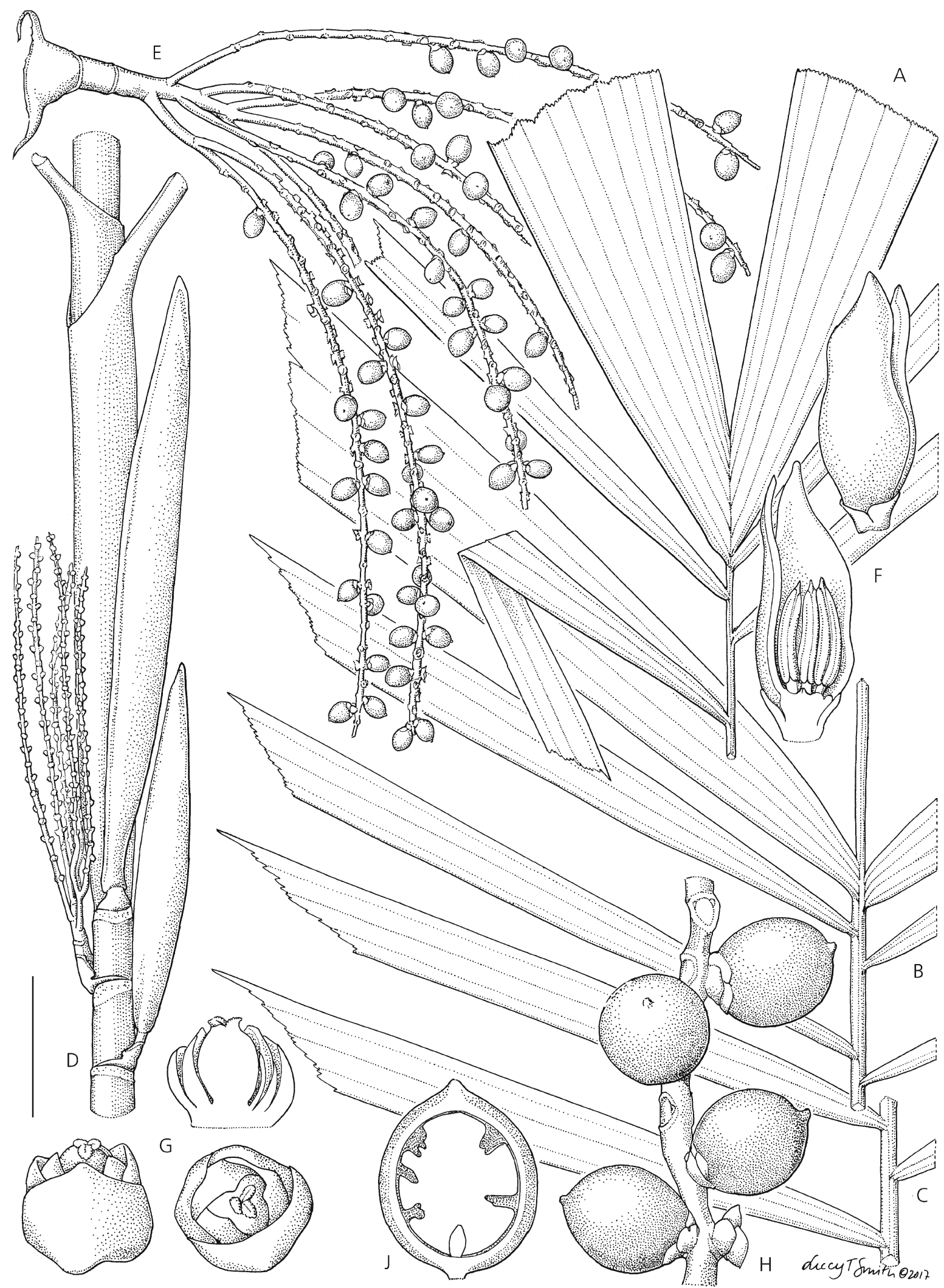

Fig. 2. Hydriastele kasesa. A leaf apex; B mid-leaf portion; C leaf base; D leaf sheaths above attached inflorescences with or without prophyll; $\mathrm{E}$ infructescence; $\mathrm{F}$ staminate flower whole and in longitudinal section; G pistillate flower whole, two views, and in longitudinal section; $\mathrm{H}$ portion of rachilla with fruits; J fruit in longitudinal section. Scale bar: A - C $8 \mathrm{~cm}$; D $6 \mathrm{~cm}$; E $4 \mathrm{~cm}$; F 5 mm; G 2.2 mm; H 1 cm; J 7 mm. All from Takeuchi 9902. DRAWN BY LUCY T. SMITH. 
$3 \mathrm{~mm}$, rounded, imbricate, internal surface striate; petals c. $1.5 \times 2.5 \mathrm{~mm}$, rounded, with short triangular apical lobe, broadly imbricate; ovary c. $1.5 \times 1 \mathrm{~mm}$, ellipsoid; welldefined style lacking; stigma minute and congenitally exposed; staminodes absent. Fruits c. $7 \mathrm{~mm}$ long, globose to broadly ellipsoid, smooth to shallowly ridged. Seeds globose, endosperm shallowly ruminate (Fig. 3).

DISTRIBUTION. Hydriastele rheophytica is known from the Idenburg River and its upper tributaries in Papua Province, Indonesia, and, according to Dowe \& Ferrero (2000), from the Frieda River in Sandaun Province, Papua New Guinea (Map 1).

SPECIMENS EXAMINED. INDONESIA. PAPUA PROVINCE: Idenburg R., Araucaria Creek, 4 km SW of Bernhard camp, [3 ${ }^{\circ} 29^{\prime} \mathrm{S} 139^{\circ} 6$ 'E], March 1939, Brass 13700 (A!, $\mathrm{L}$ ); Same locality as preceding, [3 ${ }^{\circ} 29^{\prime} \mathrm{S} 139^{\circ} 6^{\prime} \mathrm{E}$ ], 850 m elev., March 1939, Brass 13608 (A!, L!).

HABITAT. Stream banks or river banks that are frequently subjected to inundation; c. $850 \mathrm{~m}$ elevation. LOCAL NAMES AND USES. None recorded. Cultivated as an ornamental following introduction to Australia in the 1980s (Dowe \& Ferrero 2000).

GLOBAL CONSERVATION STATUS. Data Deficient (DD). More information is needed about the distribution and abundance of this species.

NOTES. This apparently obligate rheophyte is distinguished by its pliable, mostly leaning stems, and soft, flexible leaves. These traits are often displayed by plants that grow in a rheophytic environment, on stream edges and riverbanks where frequent inundation occurs (van Steenis 1981). Hydriastele rheophytica may also be unique within the H. wendlandiana group in forming clumps with as many as 30 stems. The basal leaflets of H. rheophytica are linear and obliquely praemorse at the tip, prompting comparison with $H$. variabilis which has pointed to obliquely praemorse basal leaflets. However, the two species differ in the terminal leaflet morphology with the most distal pair comprising $4-11$ folds in $H$. variabilis and only c. $2-3$ folds in $H$. rheophytica. Furthermore, $H$. variabilis does not display rheophytic characters.

An original Brass photo which shows this elegant palm in its native habitat was reproduced in Rheophytes of the World (van Steenis 1981).

4. Hydriastele variabilis (Becc.) Burret (1937: 483). Nenga variabilis Becc. (Beccari 1877: 26). Adelonenga variabilis (Becc.) Becc. (Beccari 1885: 82). Type: Indonesia, Papua Barat Province, Ramoi, 1872, Beccari PP426 (holotype FI!, isotype $\mathrm{K}$ !).

Nenga variabilis var. sphaerocarpa Becc. (Beccari 1877:

27). Hydriastele variabilis var. sphaerocarpa (Becc.)
Burret (1937: 483). Type: Indonesia, Papua Barat Province, Amberbakin, 1872, Beccari s.n. (holotype $\mathrm{FI}$ !, isotype $\mathrm{K}$ !).

Clustering, slender palm, $2-8 \mathrm{~m}$ tall, bearing $4-7$ leaves per crown. Stem $2-4 \mathrm{~cm}$ in diam., greenish to dark brown to blackish, blotchy; internodes 5 $14 \mathrm{~cm}$ long. Leaves 95 - $140 \mathrm{~cm}$ long including petiole; sheath $27-45 \mathrm{~cm}$ long, green, with laceratepeltate, dark purple scales attached to ferrugineous filaments, sometimes additionally covered with scurfy scales and whitish bloom, crownshaft $33-70 \mathrm{~cm}$ long; petiole $9-30 \mathrm{~cm}$ long, indumentum as sheath; rachis 50 - $110 \mathrm{~cm}$ long, indumentum as sheath; leaflets $11-23$ each side of rachis, arranged regularly to subregularly, borne $2.5-7 \mathrm{~cm}$ apart, \pm horizontally held in a single plane with tips drooping slightly, linear, transverse veinlets obscure, with ramenta; terminal leaflets $20-44$ $\times 2-10 \mathrm{~cm}$, comprising $4-11$ folds, praemorse apically; longest middle leaflet $40-80 \times 1.2-3 \mathrm{~cm}$, single-fold, praemorse apically; basal leaflets single-fold, pointed or obliquely praemorse apically. Inflorescences $10-25 \mathrm{~cm}$ long including $2-2.5 \mathrm{~cm}$ peduncle, branched to 1 or 2 orders; prophyll not seen, caducous; first peduncular bract attached $0.3-0.5 \mathrm{~cm}$ above the prophyll; primary branches $6-11$, to $22 \mathrm{~cm}$ long, closely spaced and bearing up to 1 rachilla each; rachillae to $22 \mathrm{~cm}$ long, 1 $2.5 \mathrm{~mm}$ in diam.; triads c. 3-5 mm apart, opposite and decussate. Staminate flowers not seen. Pistillate flowers $2-$ $2.5 \times 2-3 \mathrm{~mm}$ when dry, shortly after anthesis, \pm conical; sepals c. $2 \times 2-3 \mathrm{~mm}$, connate at the base, rounded, imbricate, interior surface striate; petals $2-2.5 \times 2.5-3$ $\mathrm{mm}$, rounded, broadly imbricate; ovary $2-2.5 \times 1.2-1.5$ $\mathrm{mm}$, ovoid to ellipsoid; well-defined style lacking; stigma minute and congenitally exposed; staminodes c. 2, toothlike and minute. Fruits $10-12 \times 6.3-7.8 \mathrm{~mm}$ when ripe, ellipsoid to ovoid with ends tapering when dry, smooth, drying ridged; perianth appressed to the fruit; pericarp c. $0.8 \mathrm{~mm}$ thick, epicarp red. Seeds $7-8.2 \times 5-6 \mathrm{~mm}$, ovoid; hilum lateral, elongate; endosperm deeply ruminate (Fig. 4).

DISTRIBUTION. Hydriastele variabilis occurs in Papua Barat Province, Indonesia, with most records from the Bird's Head Peninsula (Map 1).

SPECIMENS EXAMINED. INDONESIA. PAPUA BARAT PROVINCE: Ramoi, 1872, Beccari PP426 (FI!, K!); Amberbakin, 1872, Beccari s.n. (FI!, K!); Manokwari Distr., Bintuni Sub-distr., beside trail between Saengga \& Tanah Merah Villages, [2 ${ }^{\circ} 27^{\prime S} 133^{\circ} 7^{\prime} \mathrm{E}$ ], $20 \mathrm{~m}$ elev., 13 Feb. 2002, Maturbongs 712 (BO, K!, LAE, MAN); Manokwari Distr., Bintuni Sub-distr., near Saengga Village, [2²7'S $133^{\circ} 6^{\prime} \mathrm{E}$ ], $20 \mathrm{~m}$ elev., 13 Feb. 2002, Sambas 17 (BO, K!, LAE, MAN); Manokwari, around a construction main road of Manokwari-Sorong, between 


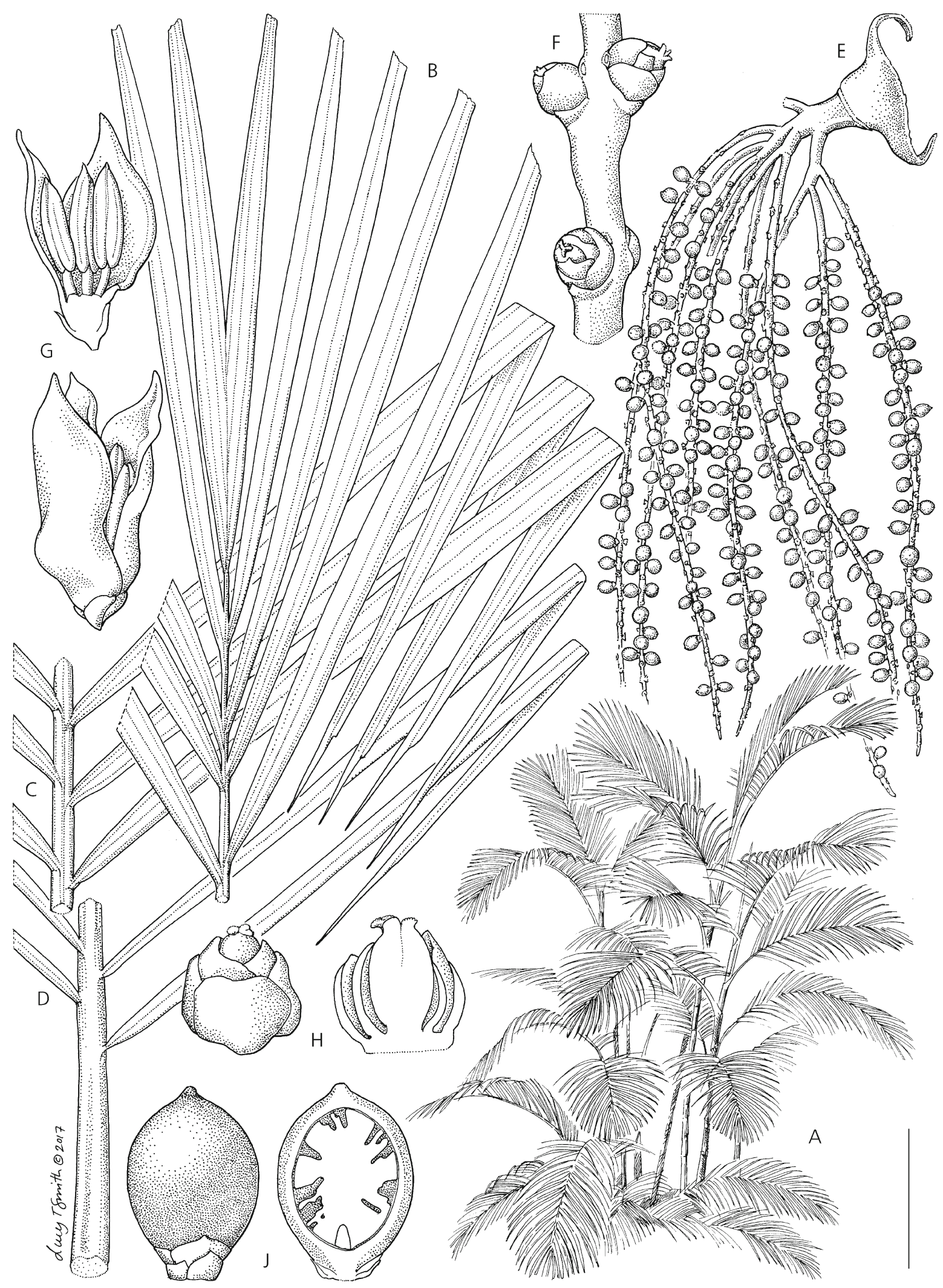

Fig. 3. Hydriastele rheophytica. A habit; B leaf apex; C mid-leaf portion; D leaf base; E infructescence; $\mathrm{F}$ portion of rachilla with pistillate flowers; $\mathrm{G}$ staminate flower whole and in longitudinal section; $\mathrm{H}$ pistillate flower whole and in longitudinal section; J fruit whole and in longitudinal section. Scale bar: A 70 cm; B - D 6 cm; E 4 cm; F- G 5 mm; H 2.5 mm; J 5 mm. A, J from Dowe 536; B - H from Brass 13700. DRAWN BY LUCYT. SMITH. 


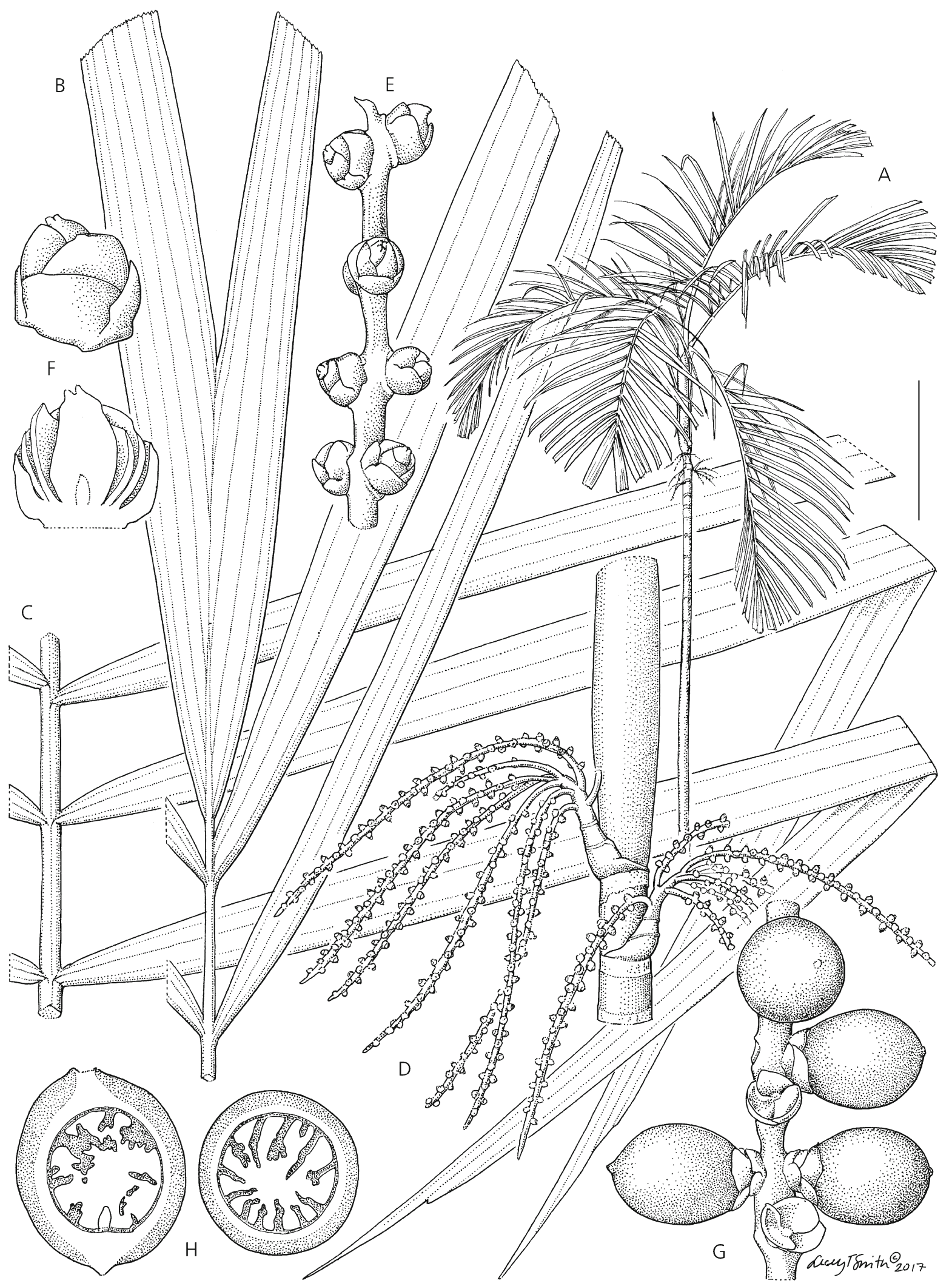

Fig. 4. Hydriastele variabilis. A habit; B leaf apex; C mid-leaf portion; D attached inflorescences with pistillate flowers; E portion of rachilla with pistillate flowers; $F$ pistillate flower whole and in longitudinal section; $G$ portion of rachilla with fruits; $H$ fruit in longitudinal and transverse section. Scale bar: A $40 \mathrm{~cm}$; B - C 4; D $6 \mathrm{~cm}$; E $1 \mathrm{~cm} ; \mathrm{F} 3 \mathrm{~mm}$; G $1.5 \mathrm{~cm}$; H $7 \mathrm{~mm}$. A, D - F from Gardiner 424; B - C, G - H from Baker 1369. DRAWN BY LUCY T. SMITH. 
Wariori R. and Waramoi R., [0 ${ }^{\circ} 48^{\prime} \mathrm{S} 133^{\circ} 38^{\prime} \mathrm{E}$ ], $400 \mathrm{~m}$ elev., 26 April 1994, Mogea 6305 (AAU, BO, BRI, K!, L, MAN, NY); Manokwari, Kebar, Kebar Valley, trail from Andjai to G. Nettoti near base camp 'N' on ridge at 1000 m, [046'S 133' $3^{\prime} \mathrm{E}$ ], 1240 m elev., 3 May 1995, Davis 726 (BO, BRI, K!, MAN, NY); Sorong, Klasaman, Km 27, Intimpura Camp, [0 $58^{\prime} \mathrm{S} 131^{\circ} 28^{\prime} \mathrm{E}$ ], $120 \mathrm{~m}$ elev., 20 Sept. 1995, Maturbongs 292 (K!); Sorong, Klasaman, KM14, [055'S 131 ${ }^{\circ} 22^{\prime} \mathrm{E}$ ], 40 m elev., 15 Sept. 1995, Wally 464 (K!); Sorong, Roefei R. N of Sorong, c. 2 miles from the sea on northern bank, [0 ${ }^{\circ} 51^{\prime} \mathrm{S} 131^{\circ} 15^{\prime} \mathrm{E}$ ], $90 \mathrm{~m}$ elev., 24 March 1954, van Royen 3155 (CANB!, L!); Sorong Distr., Klasaman, Klabainem, [0 $\left.{ }^{\circ} 55^{\prime} \mathrm{S} 131^{\circ} 20 ' \mathrm{E}\right], 10 \mathrm{~m}$ elev., 29 Feb. 2002, Heatubun 375 (K!, MAN); Tamrau Mts, Sorong-Manokwari road, beyond Bamus Buma, towards Fef and Manokwari, [0 $45^{\prime} \mathrm{S} 132^{\circ} 17^{\prime} \mathrm{E}$ ], $950 \mathrm{~m}$ elev., 28 Jan. 2013, Gardiner 424 (BO, K!, L, MAN); Tambrouw Regency, Fef Distr.; Pass above Fef, [0 $49^{\circ} \mathrm{S}$ 132²7'E], $700 \mathrm{~m}$ elev., 24 Jan. 2013, Baker et al. 1369 (BO, K!, L, MAN); Sorong Regency, Klaso Distr.; Kalalin, near Megame, [046'S 131 49'E], $100 \mathrm{~m}$ elev., 31 Jan. 2013, Baker et al. 1390 (BO, K!, L, MAN); Locality info lacking, Iwanggin 134 (MAN, K!).

HABITAT. This species is occasional to locally abundant in pristine or degraded lowland tropical rainforest, sometimes growing near creeks or adjacent to savannah or swamp forest, and on slopes in premontane primary forest on soils with a varying composition of clay, sand, humus and fibrous roots; $0-1200 \mathrm{~m}$ elevation.

LOCAL NAMES AND USES. sagarofa (Sumuri), pinang oetan (Malay). No recorded uses.

GLOBAL CONSERVATION STATUS. Least Concern (LC). The EOO of Hydriastele variabilis is c. $26,000 \mathrm{~km}^{2}$ and the AOO is $44 \mathrm{~km}^{2}$ with the latter figure likely to be a low estimate resulting from under-collecting. It has been observed in some forested areas now known to have been replaced by oil palm plantations, the expansion of which may pose a future threat to this species compounded by its relatively narrow distribution.

NOTES. This species is distinguished by its slender habit, bearing $4-7$ petiolate leaves per crown, and leaflets that are regularly arranged with the basal ones being linear and pointed to obliquely praemorse at the tip, and the terminal pair comprising $4-11$ folds. Some resemblance to this basal leaflet morphology is seen in Hydriastele apetiolata and H. rheophytica but the apetiolate adult leaves and bifid juvenile leaves are highly distinctive in the former species, and the latter species has terminal leaflets comprising c. $2-3$ folds and also displays rheophytic characters such as pliable stems. Confusion with $H$. wendlandiana is unlikely as this species usually has irregularly arranged leaflets, the basal ones of which are truncately praemorse apically.
In the protologue for Hydriastele variabilis the staminate flower morphology is described in detail by Beccari (1877) from the type specimen Beccari PP426.

5. Hydriastele wendlandiana (F. Muell.) H. Wendl. $\mathcal{E}$ Drude (Wendland \& Drude 1875: 209). Kentia wendlandiana F. Muell. (Mueller 1870: 102). Type: Australia, Northern Territory, Liverpool R., 1867, Gulliver s.n. (holotype MEL!, isotype BRI, K!).

Hydriastele wendlandiana var. microcarpa $\mathrm{H}$. Wendl. \& Drude (Wendland \& Drude 1875: 210). Type: Australia, Queensland, O'Connell R., Nernst s.n. (location of holotype unknown, not at MEL). Nenga geelvinkiana Becc. (Beccari 1877: 28). Adelonenga geelvinkiana (Becc.) Becc. (Beccari 1885: 82). Hydriastele geelvinkiana (Becc.) Burret (1937: 484). Type: Indonesia, Papua Province, Geelvinck Bay, April 1875, Beccari s.n. (holotype FI!, isotype K!). synon. nov.

Hydriastele douglasiana F. M. Bailey (1897: 232). Type: Australia, Queensland, Cape York Peninsula, Somerset, Polo Creek, June 1897, Jardine s.n. (holotype BRI!; cf. note in Baker \& Loo [2004]).

Kentia microspadix Warb. ex K. Schum. \& Lauterb. (Schumann \& Lauterbach 1900: 206). Adelonenga microspadix (Warb. ex K. Schum. \& Lauterb.) Becc. (Beccari 1914: 26). Hydriastele microspadix (Warb. ex K. Schum. \& Lauterb.) Burret (1937: 484). Type: Papua New Guinea, Madang Province, Hatzfeldhafen, Warburg s.n. (lectotype FI!; selected by Baker \& Loo [2004]). synon. nov.

Ptychosperma beccarianum Warb. ex K. Schum. \& Lauterb. (Schumann \& Lauterbach 1900: 208). nom. nud.

Hydriastele beccariana Burret (1928: 292). Type: Indonesia, Papua Province, Noord R [43'ㅅ $138^{\circ} 43^{\prime} \mathrm{E}$ ], 25 Aug. 1907, Versteeg 1662 (holotype $\mathrm{B} \dagger$, isotypes BO, FI!, K!, L!). synon. nov.

Hydriastele carrii Burret (1936: 326). Type: Papua New Guinea, 1935, Carr s.n. (holotype B十). Neotype selected here: Papua New Guinea, Central Province, Koitaki, 22 Aug. 1935, Carr 12657 (neotype K!; isoneotypes A!, L!, NY!, SING!). synon. nov.

Hydriastele rostrata Burret (1937: 484). Type: Cultivated in Bogor Botanic Garden ex New Guinea, V1 4, April - May 1936, Furtado SFN 31139 (holotype B $\uparrow$, isotypes A!, K!, L!, SING). synon. nov.

Hydriastele lepidota Burret (1939: 204). Type: Papua New Guinea, Western Province, Tarara, Wassi Kussa R [8 $\left.55^{\circ} \mathrm{S} 141^{\circ} 55^{\prime} \mathrm{E}\right]$, Jan. 1937, Brass 8701A (holotype A!, isotypes BRI, L). synon. nov.

Solitary or clustering, slender to moderate palm with 3 - 10 stems per clump, $1-17 \mathrm{~m}$ tall, bearing 5 - 10 (12) leaves per crown. Stem $2-10 \mathrm{~cm}$ in diam., smooth, 
with grey, brown and green blotches; internodes 2 $25 \mathrm{~cm}$ long. Leaves $1-2.5 \mathrm{~m}$ long including petiole; sheath $40-73 \mathrm{~cm}$ long, yellowish to grey to green, with lacerate-peltate, dark purple scales sometimes attached to ferrugineous filaments and covered by \pm aggregated, scurfy scales, occasionally with white bloom, crownshaft $30-160(-240) \mathrm{cm}$ long; petiole (2 -) 10 $80 \mathrm{~cm}$ long, indumentum as sheath; rachis $38-190 \mathrm{~cm}$ long, slightly arching, indumentum as petiole; leaflets 12 30 each side of rachis, mostly single-fold, arranged regularly or more frequently irregularly with varying distances between leaflets and a break just above a group of closely spaced single- or bi-fold leaflets in different planes in the middle of rachis, cuneate and praemorse apically, ramenta usually present, adaxially mid to dark green and somewhat glossy, abaxially paler green, transverse veinlets obscure, thick and papery to more thin and stiff; terminal leaflets $15-42 \times(1.5-) 3-20 \mathrm{~cm}$, comprising (1-) 3-16 folds; middle leaflets $35-71 \times 2-8$ $\mathrm{cm}$; basal leaflets truncately praemorse apically. Inflorescences $(16-) 21-50 \mathrm{~cm}$ long including $2.5-7 \mathrm{~cm}$ peduncle, with (1 -) 2 (-3) orders of branching; prophyll $27-50 \times 4-7 \mathrm{~cm}$, glabrous; first peduncular bract attached $0.5-2 \mathrm{~cm}$ above the prophyll; primary branches $8-15$, to $46 \mathrm{~cm}$ long, closely spaced and bearing up to 5 rachillae each; rachillae to $43 \mathrm{~cm}$ long, $1-3 \mathrm{~mm}$ in diam.; triads 2.5-10 mm apart, opposite and decussate. Staminate flowers $8-10 \times 3-5 \mathrm{~mm}$ shortly before anthesis, creamy white; calyx $1-2 \times 2-3.5 \mathrm{~mm}$, sessile, with 3 slightly different triangular and basally connate sepals; petals unequal in size $7-9.5 \times 2.5-5 \mathrm{~mm}$, valvate; stamens (5-) $6(-8)$; filaments $0.3-1 \times 0.1-0.5 \mathrm{~mm}$, variously epipetalous, tubular to conical; anthers $3-5 \times 0.3-1$ mm, \pm pointed; pistillodes $2-4$ minute lobes. Pistillate flowers $1.8-3 \times 1.8-2.5 \mathrm{~mm}$ at anthesis, greenish, \pm conical; sepals $1.3-2 \times 1.8-2.5 \mathrm{~mm}$, rounded, imbricate, internal surface striate; petals $1.3-2.5 \times 2.5-3 \mathrm{~mm}$, rounded but occasionally with short apical lobe, broadly imbricate; ovary c. $1-1.8 \times 1 \mathrm{~mm}$, globose to ellipsoid to ovoid; well-defined style lacking; stigma minute and congenitally exposed; staminodes $1-3$, tooth-like and minute. Fruits $7-9(-11) \times 6-8 \mathrm{~mm}$ when ripe, globose to ovoid, smooth and drying wrinkled or ridged; perianth appressed to the fruit; pericarp c. $0.8-1.2 \mathrm{~mm}$ thick, epicarp orange, purple or various shades of red. Seeds $5-$ $7 \times 5-6.2 \mathrm{~mm}$, globose to ovoid; hilum lateral, elongate; endosperm homogeneous or \pm ruminate (Fig. 5).

DISTRIBUTION. Hydriastele wendlandiana is widespread in Queensland and Northern Territory (northern Australia), New Guinea and on islands in between (Map 1).

SPECIMENS EXAMINED. AUSTRALIA. NORTHERN TERRITORY: Liverpool R., 1867, Gulliver s.n. (BRI, K!, MEL!); Arnhem Land, Gulumarri, Elcho Island, [11 $56^{\prime} \mathrm{S}$ 135²9'E], 18 July 1975, Latz 6269 (CANB, DNA, K!,
NSW); Arnhem Land, Giddy R. Crossing, [12²2'S $136^{\circ} 42^{\prime} \mathrm{E}$ ], 20 June 1972, Maconochie 1550 (DNA, K!); Arnhem Land, N side of Tomkinson R c. $13 \mathrm{~km} \mathrm{~S}$ of Maningrida, [12 ${ }^{\circ} 10^{\prime} \mathrm{S} 134^{\circ} 15^{\prime} \mathrm{E}$ ], 1974, Rodd 2912 (DNA, K!); Robins Falls, 105 km SSE of Darwin, [13ํำ'S $\left.131^{\circ} 7^{\prime} \mathrm{E}\right], 1974$, Rodd 2908 (K!, NSW); Robins Falls, $105 \mathrm{~km}$ SSE of Darwin, [13 $\left.21^{\circ} \mathrm{S} 131^{\circ} 7^{\prime} \mathrm{E}\right], 1974$, Rodd 2909 (K!, NSW); QUEENSLAND: Coconut creek, $8 \mathrm{~km}$ upstream from Beagle North Camp c. $45 \mathrm{~km}$ NNE of Aurukun, [12 $57^{\prime} \mathrm{S} 141^{\circ} 49^{\prime} \mathrm{E}$ ], $50 \mathrm{~m}$ elev., 27 May 1982, Clarkson 4356 (BRI, K!); Cape Sidmouth,

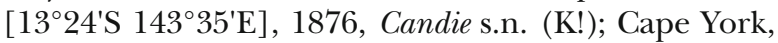
1875, Hill 5 (K!); Cape York Peninsula, Somerset, Polo Creek, June 1897, Jardine s.n. (BRI!); Cape York Peninsula, Bamaga Mission, 11.2 km SW of Cape York, $\mathrm{E}$ to mill and beyond, stony red hill, [10 53 'S 142 24'E], 24 Oct. 1965, Smith 12413 (BRI, K!, L!); Cape York Peninsula, Newcastle Bay, 2.5 miles S of Somerset, [10 $47^{\prime} \mathrm{S} 142^{\circ} 33$ 'E], $20 \mathrm{~m}$ elev., 9 May 1948, Brass 18722 (A, K!, L!); Cape York Peninsula, Iron Range, [12 $\left.{ }^{\circ} 43^{\prime} \mathrm{S} 143^{\circ} 12^{\prime} \mathrm{E}\right], 150 \mathrm{~m}$ elev., 18 June 1948, Brass 19250 (A, K!, L!). INDONESIA. MALUKU PROVINCE: Aru Islands, Pulau Trangan, $6 \mathrm{~km} \mathrm{~S}$ of Sia, [6 ${ }^{\circ} 50^{\prime} \mathrm{S} 134^{\circ} 17^{\prime} \mathrm{E}$ ], $10 \mathrm{~m}$ elev., 22 Oct. 1994, van Balgooy 6588 (K!, L!); PAPUA BARAT PROVINCE: Rajah Ampat Regency, N Misool Island, about $20 \mathrm{~km} \mathrm{~W}$ of Waigama Village near Motlol Camp, [1 ${ }^{\circ} 53$ 'S $129^{\circ} 44$ 'E], 10 m elev., 22 Jan. 2002, Maturbongs 701 (BO, FTG, K!, L, LAE, MAN); South Sorong Regency, Sayal village, Maampow forest, [1 ${ }^{\circ} 28^{\prime} \mathrm{S} 131^{\circ} 53 ' \mathrm{E}$ ], $10 \mathrm{~m}$ elev., 21 Feb. 2003, Heatubun 416 (BO, K!, MAN); Sorong, Makbalim, Aimas (SP4), [1 $\left.{ }^{\circ} 4^{\prime} \mathrm{S} 131^{\circ} 24^{\prime} \mathrm{E}\right], 50$ m elev., 1 July 1997, Heatubun 152 (K!); Manokwari Distr., mts S of Arfak Plains, steep ridges between the Arfak plains and Gunung Itsiwei, [0 $\left.{ }^{\circ} 51^{\prime} \mathrm{S} 133^{\circ} 37^{\prime} \mathrm{E}\right]$, 625 m elev., 26 April 1994, Sands 6354 (BO, K!, MAN); Manokwari Distr., Tatbei Ridge above Warmare, [047'S 1335'ㄹ ${ }^{\circ}$, $495 \mathrm{~m}$ elev., 24 Aug. 1995, Zona 688 (BO, FTG, K!, MAN); Manokwari Regency, Manokwari Distr., Warmare, Prafi R. Valley, [0 $47^{\circ} \mathrm{S}$ 1335'ㄹ], 375 m elev., 25 Aug. 1995, Zona 690 (BO, FTG, K!, MAN); Manokwari Regency, Manokwari, Cultivated, in the front of a mosque within the university area, Amban., [0 $51^{\circ} \mathrm{S} 134^{\circ} 4^{\prime} \mathrm{E}$ ], $120 \mathrm{~m}$ elev., 13 Aug. 1995, Keim 3 (K!); Teluk Wondama Regency, Wasior Distr., Wandammen Peninsula, near Dotir village, $11 \mathrm{~km} \mathrm{~N}$ of Wasior, near the confluence of the Mawoi R. and the Yois R., [2 ${ }^{\circ} 37^{\prime} \mathrm{S} 134^{\circ} 29^{\prime} \mathrm{E}$ ], $50 \mathrm{~m}$ elev., 20 Feb. 2000, Baker et al. 1043 (BO, K!, MAN); Teluk Wondama Regency, Wasior Distr., Vicinity of Wosimi R., Sikama R., $3 \mathrm{~km}$ SE of Senderawoi village, $26 \mathrm{~km}$ SSE of Wasior, [2 ${ }^{\circ} 57^{\prime} \mathrm{S} 134^{\circ} 34^{\prime} \mathrm{E}$ ], $150 \mathrm{~m}$ elev., 26 Feb. 2000, Baker et al. 1065 (BO, K!, L, MAN); Teluk Wondama Regency, Wasior Distr., Wandammen peninsula, near Wondiwoi Village, c. $9 \mathrm{~km} \mathrm{~S}$ of Wasior, [248'S $134^{\circ} 32^{\prime} \mathrm{E}$ ], 23 Feb. 2000, Rustiami 36 (BO, K!, 


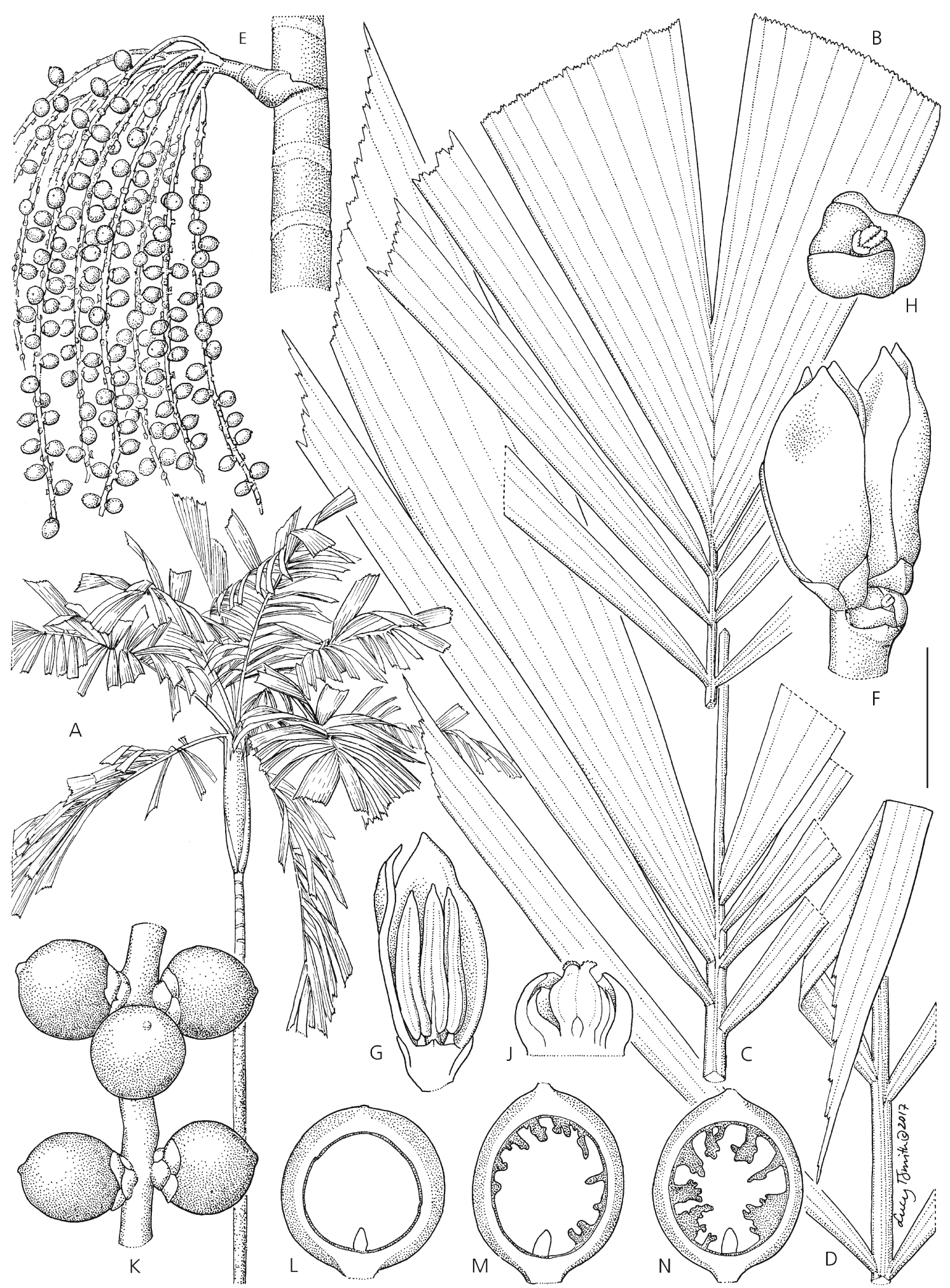

Fig. 5. Hydriastele wendlandiana. A habit; B leaf apex; C mid-leaf portion; D leaf base; E attached infructescence; F triad; G staminate flower in longitudinal section; $\mathrm{H}$ pistillate flower; J pistillate flower in longitudinal section; $\mathrm{K}$ portion of rachilla with fruits; $\mathrm{L}-\mathrm{N}$ fruit in longitudinal section: $\mathrm{L}$ homogeneous endosperm; $\mathrm{M}$ shallowly ruminate endosperm; $\mathrm{N}$ ruminate endosperm. Scale bar: A 70 cm; B - D 8 cm; E 6 cm; F - G 5 mm; H - J 2.5 mm; K $1.5 \mathrm{~cm}$; L - N 7 mm. A, F - J from Baker 1106; B - E, N from Klappa 151; K - L from Baker 1065; M from Baker 573. DRAWN BY LUCY T. SMITH. 
L, MAN); Teluk Bintuni Regency, Merdey Sub-distr., [1 ${ }^{\circ} 35^{\prime} \mathrm{S} 133^{\circ} 20^{\prime} \mathrm{E}$ ], $600 \mathrm{~m}$ elev., 2 Aug. 1998, Wally 844 (BO, K!, MAN); PAPUA PROVINCE: Noord R [4 $37^{\circ} \mathrm{S}$ 138 43'E], 25 Aug. 1907, Versteeg 1662 (B十, BO, FI!, K!, L!); Geelvinck Bay, April 1875, Beccari s.n. (FI!, K!); Keerom Regency, Arso Distr., Tami R., Yusfowor, [2 51 'S $140^{\circ} 48 ' \mathrm{E}$ ], $100 \mathrm{~m}$ elev., 11 March 2002, Gusbager 1 (K!, LAE, MAN); Central Mamberamo Regency, Taritatu R., $6 \mathrm{~km}$ SW of Bernhard camp, [330'S 139 5'E], $1050 \mathrm{~m}$ elev., March 1939, Brass 13045 (A!, L!); Nabire Regency, Samabusa, [3¹8'S 135 35'E], 10 m elev., 10 Feb. 2001, Heatubun 343 (AAU, K!, MAN); Nabire Regency, Km-45 road PT, Kaltim Hutama, [3 $28^{\circ} \mathrm{S} 134^{\circ} 52^{\prime} \mathrm{E}$ ], $100 \mathrm{~m}$ elev., 2 Feb. 2001, Heatubun 333 (AAU, K!, MAN); Nabire Regency, Napan, Makimi, Sungai Musairo, [33'S $135^{\circ} 45^{\prime} \mathrm{E}$ ], $5 \mathrm{~m}$ elev., 3 May 1985, Mogea 5529 (BO, K!, L); Mamberamo Raya Regency, Albatross Biv., [2 ${ }^{\circ} 18^{\prime} \mathrm{S} 138^{\circ} 2^{\prime} \mathrm{E}$ ], $75 \mathrm{~m}$ elev., Nov. 1926, van Leeuwen 11201 (K!, L!); Mimika Regency, Timika, Km 64.5 on road to Tembagapura, [4 ${ }^{\circ} 18^{\prime} \mathrm{S} 136^{\circ} 59^{\prime} \mathrm{E}$ ], $380 \mathrm{~m}$ elev., 7 Feb. 1998, Dransfield 7654 (BH, BO, K!, L, MAN); Yapen Islands Regency, Yapen Island, Jalan trans Yapen, [1 ${ }^{\circ} 45^{\prime} \mathrm{S} 136^{\circ} 15^{\prime} \mathrm{E}$ ], $700 \mathrm{~m}$ elev., 26 Oct. 1998, Maturbongs 613 (BO, FTG, K!, L, MAN); Yapen Islands Regency, Yapen island, Konti-unai village, near transyapen main road, [1 $\left.{ }^{\circ} 45^{\prime} \mathrm{S} 136^{\circ} 5^{\prime} \mathrm{E}\right], 700 \mathrm{~m}$ elev., 21 Oct. 1998, Maturbongs 596 (BO, K!, L, MAN, NY); Yapen Islands Regency, Yapen island, Konti-unai village, [1 ${ }^{\circ} 45^{\prime} \mathrm{S} 136^{\circ} 5^{\prime} \mathrm{E}$ ], $600 \mathrm{~m}$ elev., 21 Oct. 1998, Maturbongs 591 (BO, FTG, K!, L, MAN); Yapen Islands Regency, Yapen Island, Konti-unai village, trans-Yapen main road, [1 ${ }^{\circ} 45^{\prime} \mathrm{S} 136^{\circ} 5^{\prime} \mathrm{E}$ ], $800 \mathrm{~m}$ elev., 21 Oct. 1998, Maturbongs 600 (BO, FTG, K!, MAN); Jayapura Regency, Tanjung Elmo, on the edge of Sentani lake, [2 37 'S 140³0'E], 90 m elev., 19 Sept. 1998, Maturbongs 575 (BO, FTG, K!, MAN); Jayapura Regency, Angkasa, Cyclops Mts, Jayapura, [2³1'S 14043'E], 385 m elev., 9 Aug. 1998, Heatubun 269 (BO, FTG, K!, MAN); Jayapura Regency, Cyclops Mts, Jayapura, [2³0'S 140³0'E], 190 m elev., 16 Aug. 1998, Heatubun 281 (BO, FTG, K!, L, MAN, NY); Jayapura, North Cyclops Mts, [2 $30^{\prime} \mathrm{S} 140^{\circ} 32^{\prime} \mathrm{E}$ ], $20 \mathrm{~m}$ elev., 31 Jan. 2001, Desianto 8 (AAU, K!, MAN); Jayapura, Dessa TamiMonding, mouth of the R. Tami, [2 $37^{\prime} \mathrm{S} 140^{\circ} 55^{\prime} \mathrm{E}$ ], 15 m elev., 16 March 1956, Kalkman 3399 (CANB!, L); Jayapura and vicinity, [2 ${ }^{\circ} 37^{\prime} \mathrm{S} 140^{\circ} 40^{\prime} \mathrm{E}$ ], 7 July 1938, Brass 8963 (A!); Jayapura and vicinity, [2 32 'S $140^{\circ} 42^{\prime} \mathrm{E}$ ], $100 \mathrm{~m}$ elev., June 1938, Brass 8982 (A!, BRI, L!); Jayapura and vicinity [2 $32^{\prime} \mathrm{S} 140^{\circ} 42^{\prime} \mathrm{E}$ ], $60 \mathrm{~m}$ elev., June 1938, Brass 8891 (A!, BRI, L!); Merauke Regency, Kwell village, [7 $\left.7^{\circ} 10^{\prime} \mathrm{S} 140^{\circ} 50^{\prime} \mathrm{E}\right], 30$ Sept. 2000, Maturbongs 652 (AAU, BO, K!, MAN); Merauke Regency, Yanggandur village, Wasur, [8 $32^{\prime} \mathrm{S}$ $140^{\circ} 52$ 'E], 2000, Maturbongs 658 (AAU, BO, K!, MAN); UNKNOWN PROVINCE: Locality info lacking, Wally 1040 (K!). PAPUA NEW GUINEA. MADANG PROVINCE: Hatzfeldhafen, Warburg s.n. (FI!); Madang, Baitabag Village; Baitabag village conservation area, near to Christensen Research Institute, [5 ${ }^{\circ}$ 'S 145 46'E], $30 \mathrm{~m}$ elev., 10 Jan. 1996, Baker et al. 566 (BH, BO, K!, KEP); North Ambenob, Baiteta Village, [5 ${ }^{\circ} 1^{\prime} \mathrm{S} 145^{\circ} 45^{\prime} \mathrm{E}$ ], 100 m elev., 11 Jan. 1996, Baker et al. 573 (BH, FTG, K!, L); Ohu Village Conservation Area, [5²' 12 ' $145^{\circ} 41^{\prime} \mathrm{E}$ ], 150 m elev., 9 Nov. 1996, Barfod 350 (AAU!, K!); Baitabag Village, [58'S 14546'E], 2 Nov. 1999, Cizek 18 (K!); Josephstaal FMA area, along footpath towards Morasapa, W of expedition Camp 1 ('Kumamdeber') and to lower slopes $\mathrm{N}$ of the trail [9 $38^{\circ} \mathrm{S} 149^{\circ} 20^{\prime} \mathrm{E}$ ], 160 m elev., 29 July 1999, Takeuchi 13523 (A!, K!); near Merap Village, [44' $\mathrm{S} 145^{\circ} 40^{\prime} \mathrm{E}$ ], $10 \mathrm{~m}$ elev., 9 Oct. 1958, Pullen 1193 (CANB!, LAE); Lower Ramu, half mile $\mathrm{N}$ of Josephstaal airstrip, [ $4^{\circ} 44^{\prime} \mathrm{S} 145^{\circ} 1$ 'E], 75 m elev., 4 Oct. 1958, Pullen 1100 (L!, LAE, CANB!); MOROBE PROVINCE: Kanialia Wildlife Management Area, shoreline along Bulili ridge near Lababia, ultrabasics, [7 $18^{\prime} \mathrm{S} 147^{\circ} 8^{\prime} \mathrm{E}$ ], 0 m elev., 20 Feb. 2001, Takeuchi 15142 (A!); NW of Waria R., near Yai Village, [757'S 147 35'E], 200 m elev., 7 June 2001, Takeuchi 13213 (A, K!); below Red Hill, along Lae-Bulolo road 18 miles $\mathrm{W}$ of Lae, [6 $6^{\circ} 50^{\prime} \mathrm{S} 146^{\circ} 36^{\prime} \mathrm{E}$ ], $30 \mathrm{~m}$ elev., 3 Sept. 1964, Hartley 13082 (A, CANB!, L!, LAE); Busu R., [6 ${ }^{\circ} 30^{\prime} \mathrm{S} 146^{\circ} 55^{\prime} \mathrm{E}$ ], 15 Oct. 1957, White 9553 (K!, L!, LAE); Along Bulolo road, near Markham Bridge, [6 ${ }^{\circ} 45^{\prime} \mathrm{S} 147^{\circ} 0 ' \mathrm{E}$ ], $15 \mathrm{~m}$ elev., 15 Sept. 1971, Essig 55001 (BH, CANB!, L, LAE); Oomsis, [6 ${ }^{\circ} 41^{\prime} \mathrm{S}$ 146 48'E], $150 \mathrm{~m}$ elev., 18 April 1959, Brass 29249 (K!, L!, LAE); Anamapi Creek, Dengalu, Wau Subdistr., [7¹0'S 146 39 'E], $1050 \mathrm{~m}$ elev., 18 Jan. 1964, Millar 23072 (A, BRI!, K!, L, LAE!); Lae, Wafok, near Nadzab, [6 ${ }^{\circ} 33$ 'S $146^{\circ} 42^{\prime} \mathrm{E}$ ], 500 m elev., 30 Jan. 1996, Baker et al. 607 (FTG, K!, LAE); Oomsis, near Lae, [6 $6^{\circ} 45^{\prime} \mathrm{S} 147^{\circ} 0$ 'E], $100 \mathrm{~m}$ elev., 1 March 1959, White 10460 (BRI!, K, LAE!); Oomsis, near Lae, [6²5'S $147^{\circ} 0$ 'E], $450 \mathrm{~m}$ elev., July 1958, White 10194 (A, K!, LAE); Lae, [6 ${ }^{\circ} 44^{\prime} \mathrm{S} 147^{\circ} 0^{\prime} \mathrm{E}$ ], 21 July 1939, Clemens 10465 (K!, MICH); SANDAUN PROVINCE: Vanimo Distr., Krisa Village, Kilimeri CD, [2 51 'S $\left.141^{\circ} 16^{\prime} \mathrm{E}\right], 21$ May 1999, Klappa 151 (K!); Bewani, [31'S 141 ${ }^{\circ} 8^{\prime} \mathrm{E}$ ], 0 m elev., 19 March 2000, Barfod 501 (AAU, BRI, CANB, K!, LAE); Wutung Sub-Province, Oenake Range, foothills of Mt Bougainville, [2 $37^{\prime} \mathrm{S} 141^{\circ} 0$ 'E], 530 m elev., 7 Sept. 1982, Kerenga 56434 (CANB, K!, L!, LAE); Telefomin, Kak Valley, Gentry transect on slope above Nenem SE of Mianmin, [5 ${ }^{\circ}$ 'S 141 ${ }^{\circ} 35^{\prime} \mathrm{E}$ ], $940 \mathrm{~m}$ elev., 27 Oct. 1993, Frodin 3154 (K!); near Ambunti, [4 $4^{\circ} 14$ 'S $142^{\circ} 52$ 'E], 90 m elev., 8 June 1966, Hoogland 
10241 (BH, BRI, CANB, K!, L!, LAE); EAST SEPIK PROVINCE: Maprik Sub-distr., Wewak-Angoram Area, Prince Alexander range, SE side of Mt Turu above Ambakanja Village, [3 $37^{\circ} \mathrm{S} 143^{\circ} 22^{\prime} \mathrm{E}$ ], $600 \mathrm{~m}$ elev., 20 Aug. 1959, Pullen 1520 (CANB!); 31 km N of Ambunti, [356'S 14248'E], $80 \mathrm{~m}$ elev., 12 Aug. 1966, Heyligers 1537 (CANB!); Maprik Sub-distr., Prince Alexander Range, S side of Mt Turu, [3 $38^{\circ} \mathrm{S} 143^{\circ} 20^{\prime} \mathrm{E}$ ], $700 \mathrm{~m}$ elev., 25 Aug. 1959, Pullen 1601 (CANB!, LAE); 5 miles $\mathrm{N}$ of Timbunke, [4 ${ }^{\circ} 7^{\prime} \mathrm{S} 143^{\circ} 31^{\prime} \mathrm{E}$ ], $30 \mathrm{~m}$ elev., 12 Sept. 1959, Pullen 1713 (CANB!, L!, LAE); old airstrip at But, [3 ${ }^{\circ} 24^{\prime} \mathrm{S} 143^{\circ} 14 ' \mathrm{E}$ ], $75 \mathrm{~m}$ elev., 1 Aug. 1959, Pullen 1387 (CANB!, L!, LAE); Ambunti, Waskuk Hills, area around Langu and Garuka Villages, [4 $11^{\circ} \mathrm{S}$ $142^{\circ} 44^{\prime} \mathrm{E}$ ], $100 \mathrm{~m}$ elev., 28 June 1995, Regalado 1431 (A, K!, L); WESTERN PROVINCE: Tarara, Wassi Kussa R. [8 $55^{\circ}$ 'S $141^{\circ} 55^{\prime} \mathrm{E}$ ], Jan. 1937, Brass 8701A (A!, BRI); 2 miles $\mathrm{N}$ of Kiunga, [6 ${ }^{\circ} 5^{\prime} \mathrm{S} 141^{\circ} 18 ' \mathrm{E}$ ], $90 \mathrm{~m}$ elev., 11 Sept. 1967, Pullen 7302 (CANB!, L!, LAE); Oroville Camp, Fly R., $30 \mathrm{~m}$ above D'Albertis Junction, [543'S 141 7 'E], Aug. 1936, Brass 7402 (A!, BRI); Gaima, Lower Fly R., [8¹9'S 14259'E], Nov. 1936, Brass 8333 (A!, BRI, L!); Lake Daviumbu, Middle Fly R., [7³6'S $141^{\circ} 17^{\prime} \mathrm{E}$ ], Aug. 1936, Brass 7592 (A!, BRI, L!); Tarara, Wassi Kussa R., [855'S 141 $55^{\circ} \mathrm{E}$ ], Jan. 1937, Brass 8701 (A!, BRI, L!); North Fly Distr., Tabubil-Kiunga road, $11 \mathrm{~km}$ SE of Tabubil, [5 $\left.{ }^{\circ} 20^{\prime} \mathrm{S} 141^{\circ} 17^{\prime} \mathrm{E}\right], 360 \mathrm{~m}$ elev., 11 Dec. 2000, Baker et al. 1127 (AAU, K!, LAE, NY); SOUTHERN HIGHLANDS PROVINCE: Mubi R., Lake Kutubu divide near Tage, [6 $\left.{ }^{\circ} 21^{\prime} \mathrm{S} 143^{\circ} 18^{\prime} \mathrm{E}\right], 900 \mathrm{~m}$ elev., 27 Sept. 1961, Schodde 2284 (A, CANB!, L!, LAE); Mt Bosavi, near Bosavi Mission (also known as Dudessa or Ludessa Village), WWF Integrated Conservation and Development Project Area, [6 ${ }^{\circ} 28^{\prime S} 142^{\circ} 53$ 'E], 750 m elev., 5 Feb. 1996, Baker et al. 632 (BH, K!, LAE); Lake Kutubu, Wanunuku, near Tugiri, WWF Integrated Conservation and Development Project Area, [6²1'S 14313'E], 900 m elev., 13 Feb. 1996, Baker et al. 667 (BH, K!, LAE); GULF PROVINCE: Kikori Distr., TFI logging concession near Morere village, $38 \mathrm{~km} \mathrm{NE}$ of Kikori, [7 $7^{\circ} 10^{\prime} \mathrm{S} 144^{\circ} 29^{\prime} \mathrm{E}$ ], $120 \mathrm{~m}$ elev., 22 Nov. 2000, Baker et al. 1106 (AAU, K!, LAE, NY); CENTRAL PROVINCE: Koitaki, 22 Aug. 1935, Carr 12657 (A!, K!, L!, NY!, SING!); Abau Distr., Waeana Swamp, $5 \mathrm{~km}$ E of More R. Bridge, [10 ${ }^{\circ}$ 'S $148^{\circ} 32 ' \mathrm{E}$ ], 30 m elev., 23 Feb. 2004, Gideon 20333 (K!, UPNG); 12 km N of Amazon Bay, [10¹1'S 149 32'E], 60 m elev., 14 June 1969, Pullen 7588 (CANB!, L!, LAE); Mori R., Cape Rodney, [100'S 148 32'E], 15 m elev., 28 Aug. 1969, Pullen 8137 (CANB!, LAE); Kairuku Sub-distr., Maipa irstrip, [8²0'S 146 33'E], 50 m elev., 4 Sept. 1962, Darbyshire 880 (CANB!, LAE); MILNE BAY PROVINCE: Raba Raba Sub-distr., Kwagira R., Peria Creek, [9² $22^{\prime} S$ 149²3'E],
50 m elev., 30 Aug. 1953, Brass 24255 (A, CANB!, L!, LAE); Raba Raba Sub-distr., Kwagira R., Peria Creek, [9³8'S 149²0'E], 50 m elev., 5 July 1972, Essig 55219 (CANB!, LAE); end of logging road, [10 $222^{\circ} \mathrm{S} 150^{\circ} 7 ' \mathrm{E}$ ], 0 m elev., 2 March 2000, Barfod 458 (AAU, BRI, CANB, $\mathrm{K}$ !, LAE); Rossel Island, Abaleti, [11 ${ }^{\circ} 22^{\prime} \mathrm{S} 154^{\circ} 9^{\prime} \mathrm{E}$ ], 100 m elev., 29 Sept. 1956, Brass 28256 (A!, K!, L!, LAE). CULTIVATED. MALAYSIA: Kuching Semenggoh Arboretum, 2 May 1981, Dransfield 5987 (K!). NEW GUINEA: Bogor Botanic Garden ex New Guinea, V1 4, April May, 1936, Furtado SFN 31139 (A!, B†, K!, L!, SING). SINGAPORE: Singapore Botanic Gardens, Lawn Y 152B, 18 Sept. 1979, Mohd Shah s.n. (K!); Singapore Botanic Gardens, Palm Valley, Lawn W, Acc. no.: w/25/88/92, 27 April 2001, Loo 305 (K!); Singapore Botanic Gardens, Palm Valley, Lawn W, Acc. no.: Y152, 27 April 2001, Loo 306 (K!). UNITED KINGDOM: Royal Botanic Gardens, Kew, Acc. no.: 079-64.07901, Womersley (K!); Royal Botanic Gardens, Kew, Acc. no.: 486-66.48601 (K!); Royal Botanic Gardens, Kew, Acc. no.: 486-66.48601 (K!). UNITED STATES OF AMERICA: Fairchild Tropical Garden, Florida, Miami-Dade county, Coral Gables (Miami), Plot 112. 79-257A, 4 April 2001, Zona 890 (K!); Fairchild Tropical Garden, Florida, Miami-Dade county, Coral Gables (Miami), Plot 143. 81-608A, 4 April 2001, Zona 896 (K!).

HABITAT. Hydriastele wendlandiana is common in pristine or disturbed lowland rainforest, and sometimes grows along stream banks and ridge crests or in swampy areas and savannah-forest transition zones, on more or less sandy clay or ultrabasic soils. It is also frequent in premontane primary rainforest where it occasionally occurs on steep slopes and ridge tops or in swampy areas, on limestone and shales, limestone karst and volcanic soils; $0-1000 \mathrm{~m}$ elevation.

LOCAL NAMES AND USES. kantrabel, inpsal (Kanum), honggomi, patani, sanggum (Wondama), sal (Amele), kitat (Daga), kenege (Kutubu), upo (Meko), lai (Matbat), sirata (Sayal), kelkal (Aru Islands), bil (Mianmin), koeyauw (Yei), befer (Marap), kava kava (Patep, Buangs), sapuh (Maprik), morr (Gal), salvaik (Sempi), fabu (Ambakanja), ndzip (Timbunke), kanyaweni (Konti-unai), kaikinei (Woi).

Several uses are recorded from New Guinea: flooring (South Sorong, Morobe), roofing (Sandaun), bed construction material (Southern Highlands), arrows and/or spears (Sandaun, Southern Highlands, Merauke, Madang), harpoons (Wandammen Peninsula), chicken coops and consumption of young shoots (Merauke), ornamental (Manokwari).

GLOBAL CONSERVATION STATUS. Least Concern (LC). Hydriastele wendlandiana is very widely distributed resulting in an EOO of c. 3,287,000 $\mathrm{km}^{2}$. In New Guinea it is most likely under-collected with its AOO of 
$800 \mathrm{~km}^{2}$ likely to be a low estimate. The species' wide use amongst local people and the projected deforestation of large areas across New Guinea (Shearman et al. 2008; Global Forest Watch 2017) could pose a threat to subpopulations of this species in the future.

NOTES. This species is the most variable and widespread member of the Hydriastele wendlandiana group. It is distinguished by its petiolate leaves with $12-30$ pairs of often irregularly arranged leaflets, the basal ones of which are truncately praemorse, and leaf sheaths of $40-$ $73 \mathrm{~cm}$ in length. H. kasesa appears to be the most closely related species based on a similarity in leaflet arrangement, but it is distinguished from $H$. wendlandiana by having shorter leaf sheaths $(15-30 \mathrm{~cm}$ long) and nearly always fewer leaflets (6-13 pinnae per side). Hydriastele kasesa also normally has more slender stems than $H$. wendlandiana and smaller inflorescences with fewer primary branches. In the relatively rare cases where leaflets of $H$. wendlandiana are regularly arranged it can be mistaken for $H$. variabilis and $H$. rheophytica, however the basal leaflets in the latter two species are obliquely praemorse or pointed at the tip, never truncately praemorse as in $H$. wendlandiana.

A wide continuum of morphological variation is found within this complex species meaning that two specimens representing opposite extremes of this spectrum can appear distinct when studied in isolation. This can help explain why several morphotypes, all of which we here include within Hydriastele wendlandiana, were thought to represent different species in the past when only a few specimens were available for study. We justify broadening the circumscription of this species by not having found disjunctions in the character states of any vegetative or floral characters nor any marked character covariance patterns supporting the recognition of more than one species within the complex.

For example, seed endosperm condition, which was historically given great weight in Hydriastele taxonomy (Burret 1937), is not found to be correlated with other morphological characters in this study and a transition form between the ruminate and the homogeneous endosperm condition is present in the form of a very shallowly ruminate endosperm (e.g. Baker 573; Fig. 5M), thus calling into question the taxonomic importance and the binary nature of this seed character for this group. Zona (2005) arrived at a similar conclusion for Ptychococcus Becc. and consequently synonymised species that had previously been defined by variation in endosperm condition. Even so, by no means are we claiming that endosperm condition cannot be a useful character for delimitation of other species, it just does not appear to be the case for $H$. wendlandiana.

Our data for Hydriastele wendlandiana give some indication that geography is correlated with endosperm condition in New Guinea east of Wandammen Peninsula where we found seeds to be ruminate north of the central
New Guinea Highlands and homogeneous towards the south. However, it is quite possible that shallowly ruminate endosperm is present within individuals of H. wendlandiana in southern New Guinea but that this has not been captured by the material we have seen for this extensive area. For example, shallowly ruminate endosperm has been reported for $H$. wendlandiana in Australia (Dowe 2010) although the fertile Australian specimens cited here all had homogeneous endosperm.

One specimen (Brass 28256) from Rossel Island, Milne Bay, differs considerably from other collections and also represents the easternmost limit of Hydriastele wendlandiana (Map 1). With fruits of at least twice the volume of other fruits we have seen, and a thick and fleshy pericarp, it is tempting to describe a new species from Rossel Island, but we conclude that insufficient material is available to do so currently.

The holotype of Hydriastele carrii was likely lost in Berlin but we cannot be sure of this because the type collection number was not known by Burret and therefore not cited in the protologue (Burret 1936). Carr 12657, which we here designate as a neotype, is consistent with the protologue and, in any case, could very well be the original type collection because no other Carr specimens have been found that correspond morphologically or geographically.

\section{Acknowledgments}

We acknowledge the support of the directors and curators of the following herbaria for providing access to specimens: A, BO, BRI, CANB, FI, K, L, LAE and MEL. We are very grateful to John Dowe (James Cook University) who provided important georeferenced data for Australian specimens. Himmah Rustiami (Herbarium Bogoriense) provided valuable information on types at $\mathrm{BO}$. We also thank Lauren Gardiner and John Dransfield for their support with conservation assessments and general palm taxonomic advice. Lucy Smith prepared the botanical illustrations for this work. This research was funded by a grant to the Palms of New Guinea Project through the BAT Biodiversity Partnership and was conducted while the first author was a student on the MSc in Plant and Fungal Taxonomy, Diversity and Conservation, a joint degree delivered in collaboration between Queen Mary University of London and Royal Botanic Gardens, Kew.

Open Access This article is distributed under the terms of the Creative Commons Attribution 4.0 International License (http://creativecommons.org/ licenses/by/4.0/), which permits unrestricted use, distribution, and reproduction in any medium, provided you give appropriate credit to the original author(s) and the source, provide a link to the Creative Commons license, and indicate if changes were made. 


\section{References}

Bachman, S., Moat, J., Hill, A.W., de la Torre, J. \& Scott, B. (2011). Supporting Red List threat assessments with GeoCAT: geospatial conservation assessment tool. In: V. Smith \& L. Penev (eds), eInfrastructures for data publishing in biodiversity science. ZooKeys 150: 117 - 126.

Bailey, F. M. (1897). Contributions to the Flora of Queensland. Queensland Agric. J. 1: 228 - 235.

Baker, W. J. \& Dransfield, J. (2016). Beyond Genera Palmarum: progress and prospects in palm systematics. J. Linn. Soc., Bot. 182: 207 - 233.

\& Loo, A. H. B. (2004). A Synopsis of the Genus Hydriastele (Arecaceae). Kew Bull. 59: 61 - 68.

, Norup, M. V., Clarkson, J. J., Couvreur, T., Dowe, J., Lewis, C. E., Pintaud, J., Savolainen, V., Wilmot, T. \& Chase, M. (2011). Phylogenetic relationships among arecoid palms (Arecaceae: Arecoideae). Ann. Bot. 108: 1417 - 1432.

, Savolainen, V., Asmussen-Lange, C. B., Chase, M. W., Dransfield, J., Forest, F., Hartley, M. M., Uhl, N. W. \& Wilkinson, M. (2009). Complete GenericLevel Phylogenetic Analyses of Palms (Arecaceae) with Comparisons of Supertree and Supermatrix Approaches. Syst. Bot. 58: 240 - 256.

Beccari, O. (1877). Raccolta di osservazioni botaniche intorno alle piante dell'arcipelago Indo-Malese e Papuano. Malesia 1: 26 - 28.

(1885). Reliquiae Schefferianae illustrazione di alcune palme viventi nel Giardino Botanico di Buitenzorg. Ann. Jard. Bot. Buitenzorg 2: 82.

(1914). Neue Palmen Papuasiens. Bot. Jahrb. Syst. 52: 26.

Beentje, H. (2016). The Kew Plant Glossary: an Illustrated Dictionary of Plant Terms. Kew Publishing.

Burret, M. (1928). M. Burret, Beiträge zur Kenntnis der Palmen von Malesia, Papua und der Südsee. Repert. Spec. Nov. Regni Veg. 24: 292.

(1936). Neue Palmen aus Neuguinea. Notizbl. Bot. Gart. Berlin-Dahlem 13: 326 - 327.

(1937). Die Palmengattungen Hydriastele Wendl. et Drude und Adelonenga Becc. Notizbl. Bot. Gart. Berlin-Dahlem 13: 482 - 487.

(1939). Palmae gesammelt in Neu Guinea von L.J. Brass. J. Arnold Arbor. 20:204.

Davis, P. H. \& Heywood, V. H. (1963). Principles of Angiosperm Taxonomy. Oliver \& Boyd, Edinburgh.

Dowe, J. L. (2010). Australian Palms: Biogeography, Ecology and Systematics. CSIRO Publishing

\& Ferrero, M. D. (2000). A New Species of Rheophytic Palm from New Guinea. Palms 44: $194-197$.

Dransfield, J., Uhl, N. W., Asmussen, C. B., Baker, W. J., Madeline, M. H. \& Lewis, C. E. (2008). Genera Palmarum: The Evolution and Classification of Palms. Kew Publishing.
Essig, F. B. (1973). Pollination in Some New Guinea Palms. Principes 17: $75-83$.

(1982). A Synopsis of the Genus Gulubia. Principes 26: $159-173$.

Global Forest Watch (2017). World Resources Institute. Accessed on (6.6.17). www.globalforestwatch.org.

Govaerts, R., Dransfield, J., Zona, S., Hodel, D. R. \& Henderson, A. (2017). World Checklist of Arecaceae. Facilitated by the Royal Botanic Gardens, Kew. Published on the Internet; http:// wcsp.science.kew.org Retrieved 22 September 2017

IUCN (2001). IUCN red list categories and criteria. Version 3.1. Gland \& Cambridge: IUCN.

Lauterbach, C. (1911). Beiträge zur Flora von NeuMecklenburg. Bot. Jahrb. Syst. 45: 357.

Loo, A. H. B., Dransfield, J., Chase, M. W. \& Baker, W. J. (2006). Low-copy nuclear DNA, phylogeny and the evolution of dichogamy in the betel nut palms and their relatives (Arecinae; Arecaceae). Molec. Phylogenet. Evol. 39: 598 - 618.

McDade, L. A. (1995). Species Concepts and Problems in Practice: Insight from Botanical Monographs. Syst. Bot. 20: 606 - 622 .

Mueller, F. (1870). Fragmenta Phytographiae Australiae. 7: 102 - 104. Ex Officina Joannis Ferres, Auctoritate Gubern. Coloniae Victoriae, Melbourne.

Quantum GIS Development Team (2017). Quantum GIS Geographic Information System. Open Source Geospatial Foundation Project. http:/ / qgis.osgeo.org

Riffle, R. L., Craft, P. \& Zona, S. (2012). The Encyclopedia of Cultivated Palms. Timber Press.

Schumann, K. M. \& Lauterbach, C. (1900). Die Flora der Deutschen Schutzgebiete in der Südsee, pp. $206-207$. Gerbruder Borntraeger, Leipzig.

Shearman, C. B., Bryan, J. E., Ash, J., Hunnam, P., Mackey, B. \& Lokes, B. (2008). The State of the Forests of Papua New Guinea. Mapping the extent and condition of forest cover and measuring the drivers of forest change in the period 1972 - 2002. University of Papua New Guinea.

Thiers, B. (2017). Index Herbariorum: A global directory of public herbaria and associated staff. New York Botanical Garden's Virtual Herbarium. http:// sweetgum.nybg.org/science/ih/.

Uhl, N. W. \& Dransfield, J. (1987). Genera Palmaruma, a classification of palms based on the work of Harold E. Moore Jr. The L. H. Bailey Hortorium and the International Palm Society.

van Steenis, C. G. G. J. (1981). Rheophytes of the World. Sijthoff \& Noordhoff, The Netherlands.

Wendland, H. \& Drude, O. (1875). Palmae Australasicae. Linnaea 39: 208 - 211.

Zona, S. (2005). A Revision of Ptychococcus (Arecaceae). Syst. Bot. 30: 520 - 529. 